OUTLINE OF A BASIC NEEDS POLICY SIMULATION MODEL

ISS-PREALC

Working Paper No. 27C

The Hague, November 1985 A. Kouwenaar 

FOREWORD

This paper has been written in the context of the research project "Planning for Basic Needs in Latin America", which is sponsored by the Government of the Netherlands. Two institutions are involved in the execution of the project: The Institute of Social Studies (ISS), The Hague, Netherlands and the Programa Regional de Empleo en América Latina y el Caribe (PREALC), Santiago, Chile. The project started in September 1980 and will be finalized in March 1985.

The object of the project is to gain further insight ir: the character, the level and the structural causes of poverty and to help to design realistic policy packages aimed at the satisfaction of basic human needs within a time span of one generation in Latin America.

In the project, two parallel lines of action have beon followed: firstly, an in-depth comprehensive country study, for which Ecuador has been chosen and which aims to analyze the relation of the situation of poverty groups with the structure and functioning of the economy and secondly a series of issue studies, which concentrate on a particular basic needs item and study it on a cross-country basis. This issue studies not only diagnose the satisfaction of a particular basic need, but also review basic needs policies carried out in the countrios corsiderert.

The ISS teiam, which was composed of Jorge Alarcón, Lidia Barreiros, Arend Kouwenaar, Rudolf Teekens and Rob Vos, took as its responsability the in-depth country study for Ecuador. 
The RREALC team, consisting of Alvaro García, Ricardo Lagos, iiector Szretter, Alejandro Gutiérrez and Blas Tomic, is responsible for the issue studies.

The series of Working Papers of which this document is part addresses itself to the in-depth country study for Ecuador. It contains both theoretical and applied work in the field of basic needs planning. A similar series is produced by PREALC concerning the issue studies.

Finally, it should be noted that the research as carried out by the ISS and PREALC in this project will be published in the course of 1985 in the form of a final report, which will give a comprehensive picture of our findings.

The Hague, 10 January 1985

Rudolf Teekens 
CHAPTER 3 OUTLINE OF A BASIC NEEDS POLICY SIMULATION MODEL

3.1 Introduction.

3.1.1 Objectives of the model

3.1.2 Global characteristics

3.1.3 A SAM-based model with endogenous prices

3.1.4 Simplified mathematical structure

3.2 The structure of the model : an overview

3.2.1 Production

3.2.2 Employment and value added

3.2.3 Income distribution

3.2.4 Consumption

3.2.5 Flow of funds and investment

3.2.6 Exports and excess demands

3.2.7 Updating population and labour supply

3.2.8 Updating capital stocks and ownership

3.2.9 Basic needs indicators

3.3 Solution and use of the model

3.3.1 Solution method : tatonnement

3.3.2 Use of the method

List of tables

Table 3.1.1 A simplified general equilibrium model

List of figures

3.2.1 Structure of the model: an overview

3.2.2 Production, employment and value added

3.2.3 The income distribution process

3.2. 4 Households, government and intermediate consumption

3.2.5 Savings, flow of funds and investment

3.2.6 Exports and excess demand

3.2.7 Population, labour supply and wealth distribution

3.2.8 Basic needs indicators

3.3.1 A sketch of the solution algorithm 
7

$$
\text { , }
$$

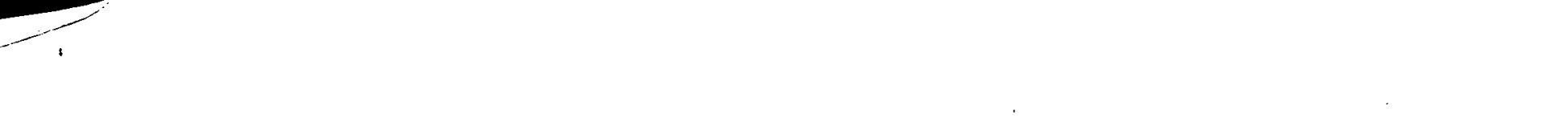


3. AN OUTLINE OF A BASIC NEEDS POLICY SIMULATION MODEL

\subsection{Introduction}

This chapter gives a global presentation of the general equilibrium model for basic needs policy. The model's structure by composing blocks is given in section 3.2. Section 3.3 discusses the solution method and indicates some possible uses of the model.

In the remainder of this introduction we shall summarise the objectives of the model, discuss its global characteristics, its relationships to a social accounting matrix (SAM) and, finally, its simplified mathematical form.

\subsubsection{Objectives of the Model}

The basic objective of the model is to develop a tool for the simulation of policies oriented towards basic needs satisfaction. For this it is necessary to capture as many interactions as possible between the various 'zones' of the society which are relevant to the issue and can be quantified in some way .

The interdependencies between the various agents of the economic and social process, i.e. productive units, households and various types of institutions, will be described, in particular the role of prices in the decision making processes. In our opinion, relative prices play a role in the allocation process; they also affect the outcome of the economic and social processes in terms of basic needs satisfaction. A general

equilibrium type of model should enable us to take the various interdependencies between agents into account as well as to do justice to the allocative role of prices. This type of model, in which excess demand on a market is assumed to lead to price adjustment in the same period so that the market clears, seems to imply a more realistic approach than fixed price models; on the other hand, certain price rigidities or price fixation can easily be built into it as special cases by adding additional "slack" or stock variables. Complete price control is probably a rare phenomenon in mixed economies and it is known that price control of ten goes together with parallel markets. 
The application of general equilibrium-type models to developing economies is a relatively recent phenomenon. 'A precondition seems to be that a number of particular rigidities and other characteristics of markets in the developing economy are taken into account (cf. section 2.2 on the role of relative prices in developing countries).

The model can be used in an attempt to reproduce the historicallyrealised values of the endogenous variables. The goodness of fit will give some indication on whether the model is "realistic", i.e. whether the underlying hypotheses including that on the importance of relative prices are justifiable. A number of models will probably be able to achieve this however, and no absolute "proof" of the assumptions will be reached.

Our type of model should not be judged by its ability to reproduce the past or to predict the future. Rather, it is meant for simulating policy packages. Its underlying assumptions should first be justified on both theoretical and empirical grounds and then incorporated into the model to produce a plausible description of economic and social mechanisms that are set into force when exogenous policy shocks are introduced. The outcomes of simulations should be considered as to whether they give a plausible indication of the direction into which the economy is going to move in response to policies. This is also where the importance of relative prices comes in and can be judged: how sensitive are the model outcomes to removal of certain price distortions - observed in reality and quantified - and to the introduction of government measures that affect relative prices?

our interest lies primarily in the impact on basic needs satisfaction. Therefore, policy simulations are aimed at quantitative evaluation of the effect of policies on the position of specific socio-economic groups. For example, one can simulate a housing programme aimed at low-income households. The model would trace the various effects and linkages: the initial effect on construction expenditure; employment and income effects, in particular of the low-income groups; effects on consumption and savings; consequences for the government balance (interest and other subsidies), for the balance of payments (increased imports and possible capital inflow), etc. Ultimately, we want to know the benefits to a household group in terms of its basic needs satisfaction. Other possible simulations are listed in section 3.3 below. The proposed analysis of basic needs policy packages 
leads to the question of what features of the model make it a basic needs policy model.

\subsubsection{Global Characteristics}

Figure 3.2.1 gives a schematic overview of the structure of the model, of which the main characteristics are the following.

\section{(i) Classifications}

The most important basic needs characteristic is the classification of the various agents in the socio-economic processes: by dividing households into socio-economic groups that are relatively homogeneous as to income and consumption behaviour and can be identified as target groups for government policies. Similarly, commodities, consumption categories and sectors are distinguished so as to identify those units that are relevant for basic needs satisfaction. The latter two are considered as distinct from the usual commodity classification because sectors can produce more than one commodity, and more than one commodity contributes to satisfying a certain need or consumption category.

Analysis of segmented labour markets makes it necessary to distinguish various occupational categories. The study of government basic needs policies requires a disaggregation of government services by type. The classifications used are listed in Appendix A6.1.1.

\section{(ii) Socio-Economic Processes}

The model describes, formally and in detail, for each of a number of socioeconomic groups, the main economic and short-run processes of income formation and expenditure on the one hand, and the more social and mediumrun processes of household and (socio-economic) group formation, of formation of the labour force, migration, as well as the processes of wealth formation and productivity growth, on the other hand (including the various interactions between these processes). Particular emphasis is placed on the role of relative prices in allocation, on income formation, income distribution and basic needs satisfaction, as well as on the dynamic longer-run effects of the latter on various aspects of the socio-economic system. 


\section{iii) Basic Needs Block}

In order to quantify the effect of the socio-economic processes on basic needs satisfaction, a number of basic needs indicators describe the "output" in terms of satisfaction or of a best proxy for satisfaction (availability and/or access); some of these indicators feedback into the system, affecting,for example, structural parameters as labour productivity, labour supply, and population growth.

(iv) Imperfect Markets

Various occurrences of non-smoothly functioning markets are captured:

- imperfect competition on commodity markets;

- a flow of funds block that captures financial intermediation, and credit rationing;

- segmentation of labour markets and specific types of labour rationing;

- product-differentiation in international trade and incorporation of various trade policies that act on prices (tariffs, exchange rate);

- various demand categories are distinguished where commodities are assumed not to be perfectly substitutable between demand categories; thus differential import dependence and effects of import substitution policies can be described;

- allowance is made for export targets implying that prices received by domestic producers are different on home and foreign markets;

- a mapping of producer prices to consumer prices (and of demand in terms of the latter to demand in the former) highlights the role of a rather monopolised sector "commerce" or domestic trade. 
3.1.3 A SAM-based model with endogenous prices

A social accounting matrix $(\text { SAM })^{2}$ gives a consistent picture of an ex post equilibrium of varlables whose nominal value appear in the cells: each cell represents a payment for a transaction between two agents. Since the SAM is only an accounting framework it does not describe the underlying technical or behavioural relationships between (row or column summations of) the cells. Nor does it distinguish price from volume components of each cell. Provided it is complemented with information on volumes or prices, the SAM is a useful basis for modelling. Some functional relationships can be calculated directly from the SAM, for example by dividing the value of an intermediate delivery by the column sum (total value of production) of a sector (input-output coefficlent), or by dividing the value of consumption of a category by total consumption (partial column sum) of a household group (expenditure shares).

Obviously, the use of a SAM for parameter calculation is restricted to linear relationships without constant. If fixed proportions between the value entries of the SAM cannot be assumed, data for other years are needed and the formation of prices that correspond to the cells are to be described. Moreover, a SAM-cell is of ten an aggregate of components that together constitute the transactions between two agents, but are related in different ways to other cells (and their components). As an accounting and classification tool, however, the SAM is very useful.

The distinction between endogenous and exogenous accounts corresponds to that of endogenous and exogenous variables; endogenous are those accounts for which expenditures (In the column) depend on the revenues (in the row) of the same accounts. In a "fixed price universe" and taking fixed proportions between cells and column totals, the endogenous variables (the column totals of the endogenous accounts) can be solved as a linear function of the exogenous variables (column totals of the exogenous accounts). 'Fixed price multipliers' are then arrived at, namely, the inverses of matrices of $f$ ixed proportions between cells and column totals? The implicit assumption is that there is no ilmitation on the endogenous variables; for example, capacity constraints are absent. Such a linear model directly grafted onto the SAM can be considered as a special case of a general equilibrium model. 


\subsubsection{Simplified mathematical structure}

The prime objective at this stage now is to maintain the overview of the structure of the model by dropping - for presentation purposes - the disaggregations and refinements that are crucial for a basic needs model and which are elaborated in the following chapters. In section 3.2 we (globally) discuss the more complicated version which includes the many basic needs characteristics which, though very important for our model, are not directly necessary and even burdensome to an understanding of the basics of a general equilibrium type model.

All equations that can easily be substituted into others have been dropped. The distinction "sectors-commodities" has also been left out for ease of exposition. For the same reason, all exogenous variables except wage rates, capital stocks and foreign savings have been omitted.

Table 3.1.1. shows the simultaneous equation system with endogenous domestic commodity prices $P D_{1} \ldots P_{K}$ and the exchange rate $E R$.

The system contains $11 \mathrm{~K}+4$ equations in $11 \mathrm{~K}+4$ unknowns; substitution reduces the system to $K+1$ excess demand equations in $K+1$ prices (incl. the exchange rate). Walras' Law Implies that one excess demand equation is dependent and one price can be chosen as numeraire. It depends on the homogeneity property (of degree zero) whether the choice of the numeraire affects the outcome.

\subsection{The structure of the model: an overview}

The model consists of a set of non-linear equations in endogenous and exogenous variables. Its condense mathematical form was shown in table 3.1.1. The various groups of equations will now be discussed, simplified as much as possible in order to advance a "heliview" on the model structure. The typical basic needs aspects of the model will be emphasised and the key moments of application of a basic needs policy identified.

The model has two major parts: (I) the main iteration part which gives a solution for the current year; and (II) the updating part, in which the exogenous variables of the main iteration part are updated for iteration of the following year as functions of the equilibrium solution of the previous period. In this sense the model can be called recursive. 
System of equations

(1)

$$
x_{k}=f\left(L_{k}, k_{k}, v_{k}\right)
$$$$
V_{k}=A_{1 k} X_{k}
$$$$
\text { (3) } \quad P_{k}=P D_{k}-\left\{A_{1 k} P_{k}\right.
$$$$
\text { (4) } \quad L_{k}=g_{k}\left(X_{k}, P N_{k}, \bar{W}_{k}\right)
$$$$
\text { (5) } Y_{L}=\xi_{k} L_{k} \bar{W}_{k}
$$$$
\text { (6) } Y K=\sum_{k}\left(X_{k} P D_{k}-L_{k} \bar{W}_{k}\right)
$$$$
\text { (7) } \quad C_{k}=c_{k}\left(Y L, Y K, P, \ldots P_{K}\right)
$$$$
\text { (8) } \quad S D=s(Y L, Y K)
$$$$
\text { (9) } I_{k}=b_{k}\left(P_{1} \ldots P_{K}\right)
$$

$$
M_{k}=m_{k}\left(\left\{C_{k}+I_{k}+V_{k}\right\}, P D_{k}, E R\right) \text { 1mport demand }
$$

$$
D_{k}=C_{k}+I_{k}+V_{k}-M_{k}
$$$$
\text { (12) } E_{k}=e_{k}\left(P D_{k}, E R\right)
$$$$
\text { (13) } \quad P_{k}=h_{k}\left(P D_{k}, E R\right)
$$

Equilibrlum conditions:

(14) $\quad D_{k}+E_{k}-X_{k}=0$

(15) $\quad \xi\left(M_{k} P M_{k}-E_{k} P D_{k}-\overline{S F} E R=0\right.$

\section{domestic demand}

export demand

composite price of domest $1 \mathrm{c}$ and 4 imported commodities

excess demands commodities equal zero

balance of payments

Because of the macro-budget constraint or Walras's Lau ye haye :

$$
\begin{aligned}
& Y+\overline{S F} E R=\frac{\sum}{k}\left(X_{k} P D_{k}-V_{k} P_{k}\right)+\overline{S F} E R^{\prime}-E\left(C_{k}+I_{k}\right) P_{k} \\
& \text { income + borrowing = value added + borrowing - expenditure }
\end{aligned}
$$

which is the sum of all equations (14) and (15) and equivalent to the usual formulation of the savings-investment 1dentity:

(16a) $\quad I=S D+\overline{S F} \quad E R$

Excess supply of domestic commodities, that is:

(17) $\sum_{k}\left(X_{k}-D_{k}-E_{k}\right) P D_{k}>0$

implies excess demand for forelgn exchange (measured in domestic currency at the exchange rate):

(17a) $\sum M_{k} \overline{P W}_{k} E R-\xi E_{k} P D_{k}-\overline{S F} E R>0$

This can rasily be shown by rewriting (16) adding $\bar{k}_{k} M_{k} \overline{P W}_{k} E R_{k}-\sum_{k} E_{k} P D_{k}$ to both sides and rearrenging terms:

(15') $\sum_{k}\left(X_{k} P D_{k}-\left(V_{k}+C_{k}+I_{k}\right) P_{k}+M_{k} \overline{P W_{k}} E R-E_{k} P D_{k}\right\}=\sum_{k} M_{k} \overline{P W_{k}} E R-\sum_{k} E_{k} P D_{k}-\overline{S F} E R$ or: $\quad E_{k}\left(X_{k}-D_{k}-E_{k}\right)^{\prime} P D=\sum_{k} M_{k} \overline{P W}_{k} E R-\sum_{k} E_{k} P D_{k}-\overline{S F} E_{R}$

Walras's Law means that the sum of all excess demands equals zero; that $1 \mathrm{~s}$, only $K$ equilibrium conditions out of $K+1$ (eq.(14),(15)) are independent; this implies that equilibrium on $K$ markets implies equilibrium on the $(K+1)$ th market.
Table 3.1 Continued

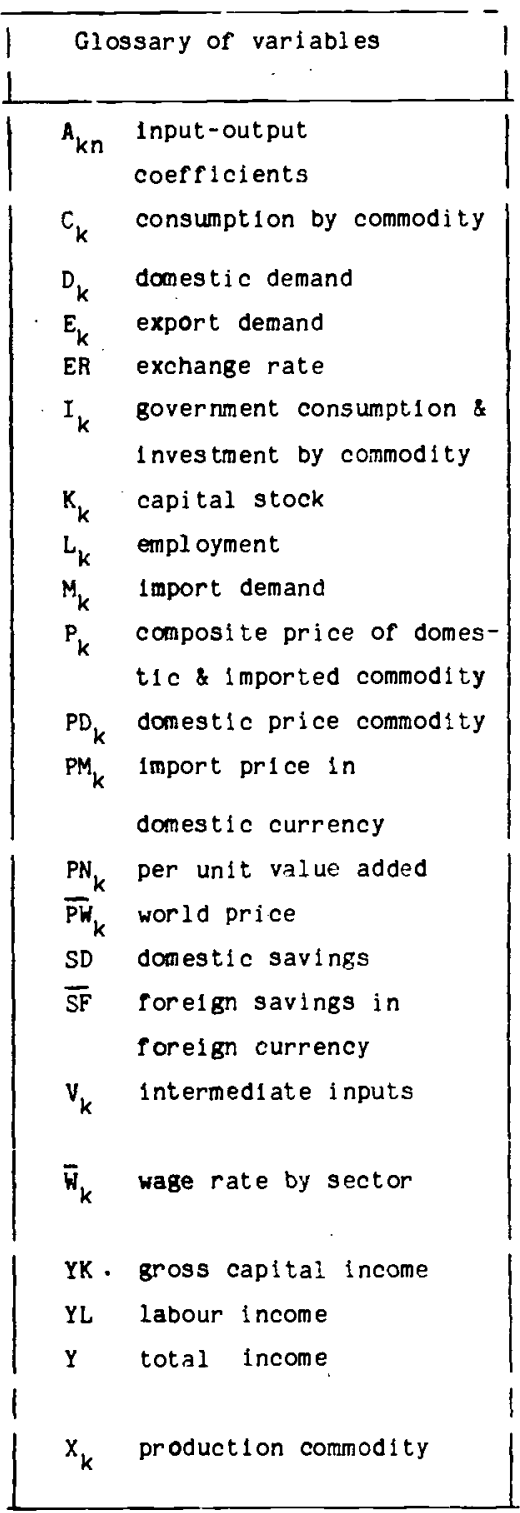


Part I. Main Iteration ${ }^{5}$

The main iteration part is basically centred around the derivation of a set of excess demand equations for commodities in as many price variables. Behind excess demands lie the state of resource ownership and the processes of production, income formation and expenditure. The equations of part I can be grouped into six blocks (see also figure 3.2.1):

1. a block describing supply of commodities by productive units (Production);

2. a block describing the distribution of employment opportunities and factor income among the various agents that own factors (Employment \& Value Added);

3. a block describing the process of transformation of factor income into secondary or disposable household income; in other words, the mapping of factorial income distribution into size income distribution (Income Distribution);

4. a block describing the formation of consumption demand: private consumption of the various socio-economic groups, public and intermediate consumption; it includes the determination of domestic and foreign components of consumption demand (Consumption);

5. a block describing the formation of investment demand: how savings of households as well as savings and credit flows of institutions are channelled ("flow-of-funds") to households and institutions to lead to investment, by investing agent, by sector of destination and by commodity of origin; domestic and foreign components of investment demand are determined (Flow-of-funds \& Investment);

6. a block describing the equations of excess demand for commodities; after export demand has been added to domestic demand for domestic commodities, total demand is confronted with domestic supply; foreign exchange is considered as one of the commodities for which an excess demand equation is defined; in equilibrium, all markets clear and the equilibrium price vector satisfies the excess demand equation (zero excess demands) (Exports \& Excess Demand). 
Figure 3.2.1: Structure of the Model: An Overview

Part 1: Main Iteration, Current Year

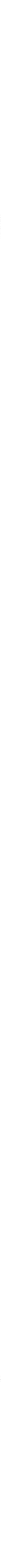

NOTES: $(E)=$ Encogenous in main 1teration, part 1 .

$(x)$ - Exogenousin main teration, but updated in part 11 . 
Part II. Updating ${ }^{6}$

7. A block in which population and labour supply by socio-economic group is determined together with the distribution of persons among households (Population \& Labour Supply);

8. a block in which capital stocks by sector and owning agent are changed as well as all distribution parameters related to capital ownership (share capital, debts-claims, self-employed shares in operating surplus); it also includes the derlvation of desired capital-output ratios (Distribution of Wealth);

9. a block in which basic needs satisfaction indicators are calculated by socio-economic group: nutrition, education, life expectancy, infant mortality, housing, drinking water and sewerage, as well as indices that describe income inequality and its sources (Basic Needs Indicators).

This section continues with global descriptions of each of the blocks.

\subsubsection{Production}

The productive capacity of a sector is described by a two-level production function which aggregates composite factors of production to a production possibility frontier; that is, the combination of outputs of commodities that can be produced with a given productive capacity.

When $z_{n}$ denotes productive capacity of sector $n(n=1, \ldots, N)$ and $x$ output of commodity $k(k=1, \ldots, K)$, the sectoral production function can be generally written as:

level 1: $z_{n}=d\left(X_{1 n}, \ldots, X_{K n}\right)$

(3.2.1a) multi-product output or production possibility set

$$
Z_{n}=f\left(\gamma_{n}, V_{n}, K_{n}, L_{n}\right) \quad(3.2 .1 b) \underset{\substack{\text { production function, properly } \\ \text { speaking }}}{\text { s. }}
$$

level 2: $v_{n}=a\left(x_{1 n}, \ldots, x_{K n}\right) \quad(3.2 .1 c)$ intermediate inputs

$$
\mathrm{K}_{\mathrm{n}}=\mathrm{k}\left(\mathrm{x}_{1 \mathrm{n}}, \ldots, \mathrm{x}_{\mathrm{Kn}}\right) \quad(3.2 .1 \mathrm{~d}) \text { capital input }
$$




$$
L_{n}=1\left(L_{1 n}, \ldots, L_{S n}\right) \quad(3.2 .1 e) \text { wage labour input }
$$

where: $z_{n} \quad$ productive capacity

$x_{k n} \quad$ output or input of commodity $k$

$\gamma_{n}$ constant in production function that describes disembodied technical progress

$V_{n}, K_{n}, L_{n}$ composite intermediate, capital and labour inputs

$\mathrm{L}_{\mathrm{sn}} \quad$ wage labour of category $\mathrm{s}(\mathrm{s}=1, \ldots \mathrm{s})$ used in sector $n$

We have adopted the fixed coefficients form for (3.2.1a): $x_{k n}=D_{k n} Z_{n}$ (3.2.1.. $\left.{ }^{\prime}\right)$; it can be considered as a special case of a constant elasticity of transformation (CET) ${ }^{7}$ function, in which the elasticity of transformation is zero. For (3.2.1b), the "narrow" production functions, CES and CD specifications were taken, whereby for fixed technical coefficients were assumed, both for the aggregate intermediate and its components:

$$
v_{n}=v_{n} z_{n}=\sum X_{k n}=\sum A_{k n} z_{n}
$$

where: $x_{k n}$ intermediate input $k$ for sector $n$

$A_{k n}$ fixed technical coefficients

For composite capital and wage labour fixed proportions are again taken: the composite factor capital of sector $n$ is composed of investment commodities of origin k:

$$
K_{n}=\sum_{k} X_{k n}=\sum_{k} \quad B_{k n} K_{n}
$$

where: $\sum_{k} B_{k n}=1$, and $K_{k n}$ investment good $k$ for sector $n$

whereas composite labour is composed of labour of various occupational categories:

$$
\mathrm{L}_{\mathrm{n}}=\sum_{\mathrm{S}} \mathrm{L}_{\mathrm{sn}}=\sum_{\mathrm{S}} \lambda_{s \mathrm{~s}} \mathrm{~L}_{\mathrm{n}}
$$

where: $\sum_{S} \lambda_{\text {Sn }}=1$ 
$\lambda_{\text {sn }}$ labour coefficient of category s for sector $n$

The first, a heterogeneous capital good of fixed composition, is applied almost without exception in the empirical literature. The second, the composite factor labour, is more of ten assumed to be of variable composition, for example, a Cobb-Douglas or CES-aggregation of various types of labour. ${ }^{8}$ The fixed coefficients approach is dictated by lack of data on substitutability between the various types of labour.

whereas the factor capital, including land, has a given sectoral availability, the factor labour is assumed to be non-sector-specific, so that only a macro-constraint per category is relevant:

$$
\sum_{n} L_{s n} \leqq\left(L S_{s}-L I_{s}\right)
$$

where: $L S_{S}-L I_{s}$ supply of wage labour of category $s, 1 . e$ total supply, $\mathrm{LS}_{\mathrm{S}}$, after selfemployment, $\mathrm{LI}_{S}$ (see below)

We assume capital to be immobile in the short run: land, machinery, buildings and other equipment are not (easily) transferred from one allocation to another. The capital stock, installed in the base year, can only change by a yearly amount of (dis)investment. The existence of such a fixed factor implies decreasing returns-to-scale to the other factors.

Planned production is not only governed by 'production possibilities', but also by market behaviour. Demand for factors of production and production decisions are ruled by profit maximization; it is assumed that producers have some control over commodity prices (imperfect competition on commodity markets). On the other hand, we assume in a first stage that producers exert no control over prices of factors (1.e. labour) which they take as given. Suppliers of labour also do this.

This leads to :

$$
\begin{aligned}
& \max \Pi_{n}=\sum_{k} P D_{k} D_{k n} Z_{n}-\sum_{k} A_{k n} P_{k} Z_{n}-L_{n} W_{n} \\
& \text { under }(3.2 .1)
\end{aligned}
$$


where: $W_{n}=\xi \lambda_{s n} W_{s n}$ sector specific price of composite labour

$P D_{k} \quad$ domestic price of commodity $k$

$W_{\text {Sn }}$ wage rate by sector and occupational category

$\pi_{n} \quad$ gross operating surplus including selfemployed income

$P_{k} \quad$ price of composite commodity $k^{9}$

Having specified eq. (3.2.19'), fixed proportions in output for each sector, we can rewrite $(3.2 .3)$ as:

$$
\Pi_{n}=P N_{n} Z_{n}-L_{n} W_{n}
$$

where: $\quad P N_{n}=\sum_{k} D_{k n} P D_{k}-\sum_{k} A_{k n} P_{k}$.

which is the net price of sectoral activity or value added per unit of sectoral composite output. ${ }^{10}$ The first order condition for a maximum is:

$$
d Z_{n} / d L_{n} P N_{n}+Z_{n} d P N_{n} / d Z_{n}=W_{n}
$$

where: $W_{n}$ price of composite labour

$$
\begin{gathered}
d P N_{n} / d Z_{n} \text { inverse of a composite demand derivative which reflects the } \\
\text { degree of imperfection of the product markets for the sector } 11
\end{gathered}
$$

part of gross operating surplus is formed by unincorporated capital income, 1.e. income from self-employment. The number of people who can be selfemployed in a sector is assumed to be proportional to the level of sectoral activity: a higher level of activity can "bear" a higher number of independent workers, implying that self-employment follows the activity level as determined in the capltalist sector (eq. 3.2.5). This might seem unfustified in sectors where self-employment dominates (i.e. small farmers). However, the production function has a very low substitution elasticity for these sectors, implying that the level of output (and therefore self-employment) hardly responds to changes in the wage rate, and is practically determined by the minimum of demand and capacity output.

In most simulations the wage rate is imposed on both sides of the market. In case of excess supply unemployment results and the wage is not competed downwards, at least not in the same perlod. In case of excess 


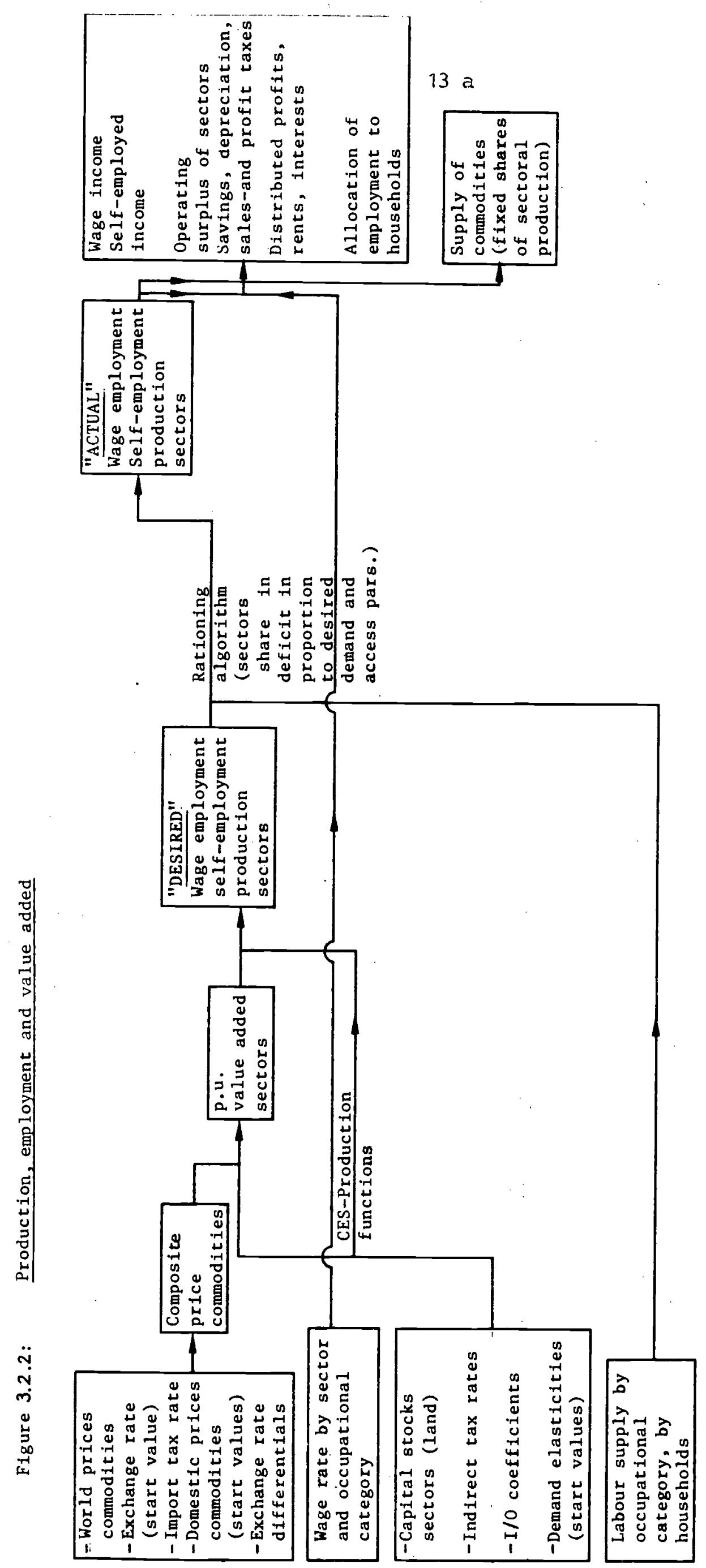


demand the available supply of labour of a certain category is rationed among demanding sectors (see below section 3.2.2).

The labour market can thus be characterised as semi-competitive: in case of excess supply all parties respond to the given price, whereas in case of excess demand a non-market rule determines allocation. Although in the longer run there might be a tendency for wages to adjust to excess demand or supply of labour, exogenously fixed wage rates seem to be a better representation of wage formation in the country under study. 12 Equations $(3.2 .1),(3.2 .4)$ and $(3.2 .5)$ lead to a set of demand functions for the composite factor labour of the form:

$$
L_{n}=1\left(W_{n}, Z_{n}, P N_{n}\right)
$$

Specification of both the production function and market behaviour also typify a sector as either modern or traditional, formal or informal: the informal part of a sector is separated as far as possible from the formal part which produces the same products, each of the two having its own technical and market characteristics. Furthermore, sectors are defined in such a way as to identify those producers that can become subject to a basic needs policy. (see section 3.1 .2 on classifications).

Equations $(3.2 .1-3.2 .5)$ describe the planned supply in the economy: given output prices, intermediate input prices, the (composite) wage rate, technology and capital stock, planned production and wage iabour demand can be determined. We use the adjective 'planned' here because in case of overall excess demand for a certain type of labour, plans have to be adjusted downward (see below section 3.2.2). Production or supply is schematically presented in figure 3.2 .2

Note that the prices of intermediates are not equal to the prices of domestic commodities since part of the inputs are imported: the composite price is a CES-aggregation of domestic and import prices:

$$
P_{k}=f\left(P D_{k}, P M_{k}\right)
$$

where: $P M_{k}$ tariff-inclusive import price in domestic currency 
The specification as outlined ensures decreasing returns-to-scale to the variable factors, which is a condition for supply curves to be upwardsloping (cf. Dervis et al. (1982: 145,171) for a recent discussion). The fixed factor receives the rent of a sectoral activity, that is, the profit as described by eq. (3.2.3). Without such a fixed factor, for example when capital is perfectly mobile in the short run and there is no third factor, constant returns-to-scale production functions would result in horizontal supply curves which, for an open economy that faces fixed world prices, would lead to complete specialisation (Samuelson (1953). However, this problem is in fact already avoided by the assumption of price differentiation in trade, the foreign price not determining the domestic price (see below equations (3.2.29)).

In our approach, rent on the fixed factor will affect, with some delay, the allocation of newly invested capital. Ceteris paribus, increased profits in a sector will increase its capital stock and shift the supply curve to the right, reducing future commodity prices relevant to the sector as well as its profits.

This block may be summarised as the derivation of a set of supply functions:

$$
\begin{aligned}
& z=f(p d, E R, w) \\
& x=D z
\end{aligned}
$$

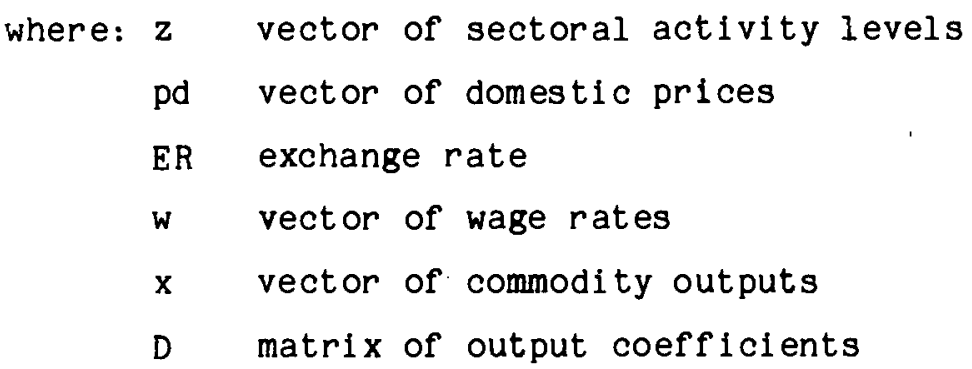

To each price vector, pd, is associated a unique sectoral price vector pn. Under certain conditions to be imposed on the production function, this gives a unique solution of desired labour inputs and desired activity levels as well as a unique vector of commodity outputs for each sector. 


\subsubsection{Employment and Value Added}

Wage labour demands by sector which are consistent with desired activity levels $Z$ have been derived from the equations in block 1. Given (3.2.1e'), total wage labour demand by occupation category also follows. If demand exceeds supply for one or more categories, supply is distributed among demanding sectors in proportion to their ex ante demand times a "rationing differential" which reflects the sector's ability to attract workers. 13

Sectoral activity levels are reduced to those that are consistent with the amount of labour in short supply which has been allocated to the sector. This approach enables sectoral labour market segmentation and differential access to labour of sectors to be described; also, it allows unemployment to occur in some sectors while excess demand prevails at the aggregate level. It should be added, however, that excess demand is likely to occur only for high-skill occupational categories. The rationing, which determines sectoral labour allocation by skill type and hence also acts as a constraint on sectoral output, is described by:

$$
L_{s n}^{a}=f\left(L_{s n}, \alpha_{s n}, L s_{s}-L_{s}\right)
$$

where: $L_{s n}^{a}$ actual wage labour allocation to a sector

$\mathrm{L}_{\mathrm{Sn}}$ desired wage labour demand of a sector

$\mathrm{LS}_{\text {S, LI }}$ total labour supply resp. self-employment

$\alpha_{n s}$ rationing parameters

Note that a lower level of output also reduces self-employment and thus "frees" labour supply for wage employment. Sectoral activity levels are now calculated at the reduced labour levels. The algorithm used ensured that outputs are not lowered too much and all of the restrictive labour category is effectively used.

From eq. (3.2.1-3.2.5) follow, by sector: commodity output, value added, wage employment and wage sum, gross profit income for selfemployed and other capital owners as well as the demand for intermediates. The wage sum of a sector is distributed according to employment by occupational 
category. Other factor income - gross operating surplus - is partly retained at the enterprise level, partly distributed to self-employed participants in the sectoral capital, and partly distributed to the owners and creditors of corporate capital:

$$
\Pi_{i}=\sum_{n} \xi_{i n}\left(P N_{n} Z_{n}-L_{n} W_{n}-U C_{n}\right)=S C_{i}+T C_{i}+C O I_{i}
$$

where: $\Pi_{i}$ gross operating surplus of institution $i$

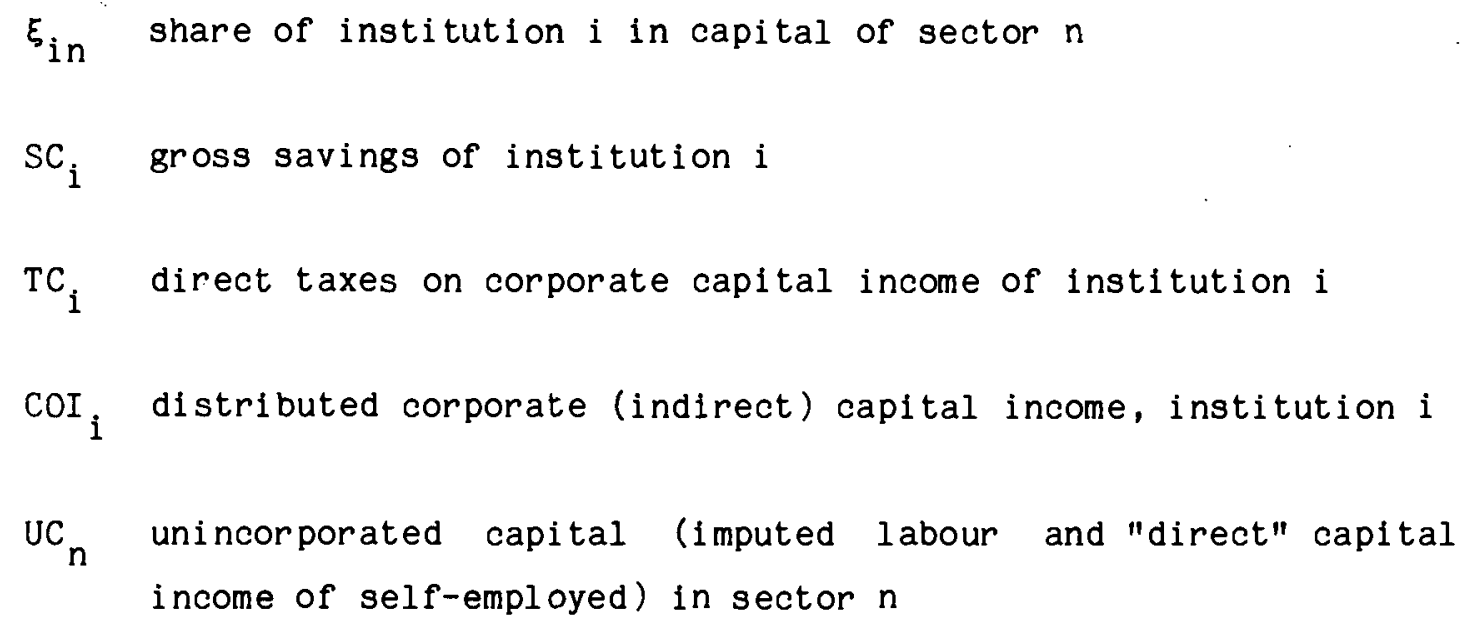

Self-employed households share in unincorporated capital income according to a weighting factor that reflects both their share in the capital stock of a sector - to be updated by investment - and their imputed market wage rate: the share goes up with capital ownership, average level of self-employment, and the average market wage. We have for unincorporated capital:

$$
U C_{n s n}=f\left(U C_{n}, L I_{s n}, W_{s n}, \xi_{s n}\right)
$$

where: LI number of self-employed by occupational category $\xi_{\text {hsn }}$ share of self-employed of household group $h$, occupational category $s$ in the sectoral capital stock

$U_{\text {hsn }}$ income of idem

As was noted above, self-employment is a fixed proportion of the level of sectoral output. This also holds for each of the occupational categories. The number of self-employed by sector and occupational category is allocated 
to socio-economic groups according to a parameter for differential access to self-employment :

$$
L I_{h s}=g\left(L I_{s n}\right)
$$

For some socio-economic groups this "access" parameter reflects lack of access to wage employment or a necessary resort to self-employment.

Households and institutions share in corporate capital income according to yearly updated shares:

$$
\operatorname{coJ}_{j}=f\left(\left\{\operatorname{COI}_{i}\right\}\right)
$$

where: $j$ refers to households and institutions

Taxes levied on corporate capital income of institutions are a function of gross operating surplus after self-employed income (neglecting interest payments):

$$
\mathrm{TC}_{1}=\mathrm{f}\left(\pi_{1}\right)
$$

Figure 3.2.2 gives a schematic presentation of the employment and value added block. The approach outlined above will enable us to introduce specific policy measures intended to affect factorial income formation to the benefit of target socio-economic groups: wage rate policies $\left(W_{s n}\right)$, household shares in operating surplus $\left(\mathrm{UC}_{\mathrm{hs}}\right)$ as well as sectoral employment policies $\left(L_{s n}^{a}\right)$.

\subsubsection{Income Distribution}

Having determined factor incomes as well as their distribution to household groups, the parametric form of the per capita disposable household income distributions is determined in block 3 .

It is assumed that household primary income (before taxes, etc.) follows a lognormal distribution whose parameters are derived from the distribution of labour income, self-employed and indirect capital income among sectors, occupational categories and households. The average and 
variance of each type of income is determined for each household group, after which the parameters of the lognormal distribution are calculated. Labour income. "Wage income is distributed among households that "own" the labour of various categories. Households "share" in wage employment opportunities for each of the occupational categories according to their supply of that type of labour as well as an access parameter:

$$
L_{h s}^{a}=f\left(B_{h s}, L S_{h s}, L_{s}^{a}, L I_{h s}\right)
$$

where: $L_{h s}^{a}, L_{s}^{a}$ actual employment; indexes $h$ resp. s refer to household group and occupational category

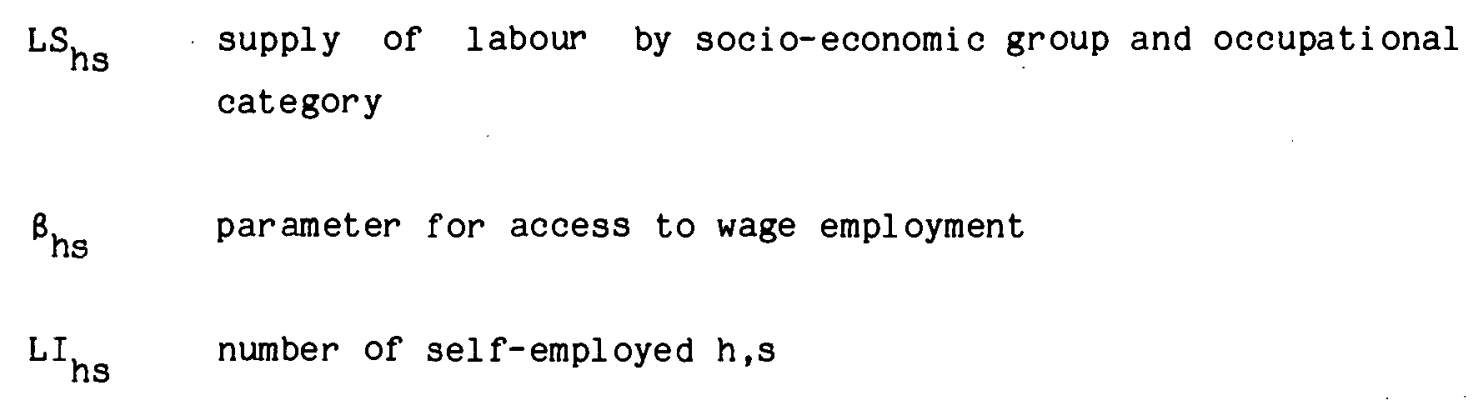

Since households share in employment opportunities by occupational category, we first determine the latter's properties (from the definitions of average and variance):

$$
\begin{aligned}
& A\left(Y W_{S}\right)=f\left(W_{s n}, L_{s n}^{a}\right) \\
& V\left(Y W_{S}\right)=g\left(W_{S n}, L_{s n}^{a}\right)
\end{aligned}
$$

where: $A\left(Y W_{S}\right), V\left(Y W_{S}\right)$ average and variance of wage of occupational category $\mathrm{s}$

$$
\begin{array}{ll}
\mathrm{W}_{\mathrm{Sn}}, \mathrm{L}_{\mathrm{sn}}^{\mathrm{a}} & \text { wage rate and actual employment by sector and occupa- } \\
& \text { tional category }
\end{array}
$$

The variance is caused by sectoral wage differences that are exogenous in the main part. However, since larger wage disparities have been observed among household groups than could be explained by disparities among occupational categories, wage differentials specific to household group have been appl ied, such that: 


$$
A\left(Y W_{h s}\right)=\delta_{h s} \cdot A\left(Y W_{s}\right)
$$

where: $A\left(Y W_{h s}\right)$ average wage of household group $h$, occupational category $s$

$$
\delta_{\text {hs }} \quad \text { differential factor }
$$

The average and variance of wage income of socio-economic group $h$ then follows from this average wage and household employment by occupational category (by definition):

$$
\begin{aligned}
& A\left(Y W_{h}\right)=f\left(A\left(Y W_{h s}\right), L_{h s}^{a}\right) \\
& A\left(Y W_{h}\right)=g\left(A\left(Y W_{h s}\right), L_{h s}^{a}\right)
\end{aligned}
$$

In the same way, the income of a self-employed is characterised by:

$$
\begin{aligned}
& A\left(Y S_{h}\right)=f\left(U C_{h s}, L I_{h s}\right) \\
& V\left(Y S_{h}\right)=g\left(U C_{h s}, L I_{h s}\right)
\end{aligned}
$$

where: $A\left(Y_{h}, V\left(Y S_{h}\right)\right.$ average and variance self-employed income, $h$

This variance of income is determined by the inequality in asset distribution among the self-employed and by the differentials in profitability between sectors.

As a third type of factor income we have indirect or corporate capital income, which each socio-economic group receives in proportion to its share in own capital of institutions; it mainly concerns shares in private enterprises. For lack of information on how this income is distributed among the various households within the socio-economic group, we have assumed an exogenous coefficient of variation.

Income earners can be (self-)employed persons as well as other nonemployed persons i.c. rentiers, pensioners etc.:

$$
A\left(Y C_{h}\right)=f\left(\operatorname{CoJ}_{h}, N_{h}\right)
$$




$$
V\left(Y C_{h}\right)=g\left(A\left(Y C_{h}\right), \bar{C} \bar{V}\left(Y C_{h}\right)\right.
$$

where: $A\left(Y C_{h}\right), V\left(Y C_{h}\right)$ average and variance of indirect capital income from institutions.
$\operatorname{coJ}_{\mathrm{h}}$
corporate capital income received by $h$ others in group $h$
$\bar{C} \bar{V}\left(Y_{n}\right) \quad$ coefficient of variation of indirect capital income
$\mathrm{N}_{\mathrm{h}} \quad$ number of income earners:employed, self-employed and

Putting the various sources of income together - and allowing for covariances between them - the mean and variance of primary income distribution among income earners may be found:

$$
\begin{aligned}
& A\left(Y P_{h}\right)=f\left(A\left(Y W_{h}\right), A\left(Y S_{h}\right), A\left(Y C_{h}\right), L_{h}^{a}, L I_{h}, N_{h}\right) \\
& V\left(Y P_{h}\right)=g\left(V\left(Y W_{h}\right), V\left(Y S_{h}\right), V\left(Y C_{h}\right), L_{h}^{a}, L I_{h}, N_{h}, \bar{C} \bar{R} \overline{1}_{h}, \bar{C} \bar{R} \overline{2}_{h}\right)
\end{aligned}
$$

where: ${ }^{Y} P_{h} \quad$ primary (incl. wage, self-employment and capital) income

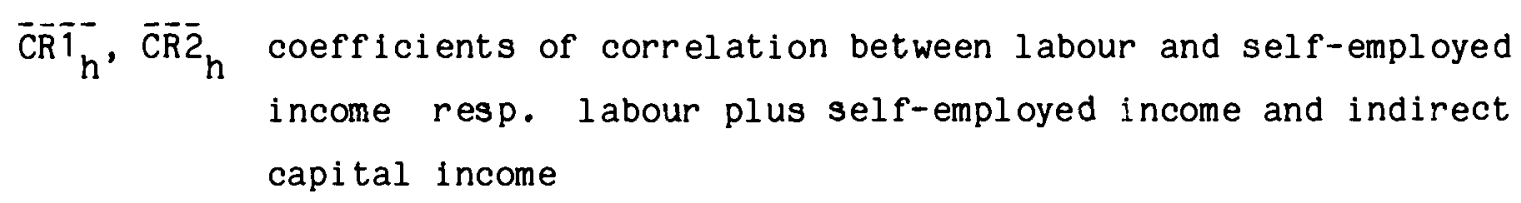

The covariances have been introduced to capture the phenomenon that a person may compensate the lack of one income source with another. Coefficients of correlation have been kept $f$ ixed, implying that individual persons allocate their time, resp. income, between wage and self-employed activities resp. consumption and savings, so as to reproduce the described correlations between sources of income. 14

Given the distribution function of the number of income earners in a household group, ${ }^{15}$ the parameters of the total household primary income distribution can be derived: our assumption, which has been confirmed empirically, is that the sum of the various income distribution processes as just described leads to an approximately lognormal distribution: 


$$
\begin{aligned}
& M\left(\left(Y P_{h}\right)=f\left(A\left(\left(Y P_{h}\right), V\left(Y P_{h}\right), A(N)_{h}, V\left(N_{h}\right)\right)\right.\right. \\
& S\left(Y P H_{h}\right)=g\left(A\left(Y P_{h}\right), V\left(Y P_{h}\right), A\left(N_{h}\right), V\left(N_{h}\right)\right)
\end{aligned}
$$

where: $A\left(N_{h}\right), V\left(N_{h}\right)$

average and variance of the number of income earners per household ( $\mathrm{N}$ )

$M\left(\mathrm{YPH}_{h}\right), \mathrm{S}\left(\mathrm{YPH}_{h}\right)$ logmean and -variance of primary household income

Household size is also assumed to follow a lognormal distribution, jointly with household income (its parameters being revised in the updating part) enabling us to switch to per capita household income distribution which will also follow a lognormal distribution with parameters:

$$
\begin{aligned}
& M\left(Y P C_{h}\right)=f\left(M\left(Y P H_{h}\right), M\left(H S_{h}\right)\right) \\
& S\left(Y P C_{h}\right)=g\left(S\left(Y P H_{h}\right), S\left(H S_{h}\right), C V_{h}(Y-S)\right.
\end{aligned}
$$

where: M(YPC ), S(YPC) logaverage and logvariance of per capita household $\mathrm{h} \quad \mathrm{h}$ income

$$
\begin{array}{ll}
M\left(\mathrm{HS}_{h}\right), \mathrm{S}\left(\mathrm{HS}_{\mathrm{h}}\right) & \text { idem household size } \\
\mathrm{CV}_{h}(Y-S) & \text { covariance between log (household income) and } \log \\
& \text { (household size) }
\end{array}
$$

Expression of household income in per capita terms can be argued, firstly, by referring to the stronger relation observed between income and consumption when specified in per capita terms. Second, per capita consumption levels are more interesting from a basic needs point of view, given the large spread in household sizes and their correlation with household income. To this distribution we apply a tax transfer function ${ }^{16}$ in order to derive the distribution of disposable household income. Above a certain per capita income threshold, households pay a net tax and social security to the government; below that threshold they receive a net transfer. Social security receipts and payments through enterprises are neglected: total net receipts per household group are practically zero, while at the individual 


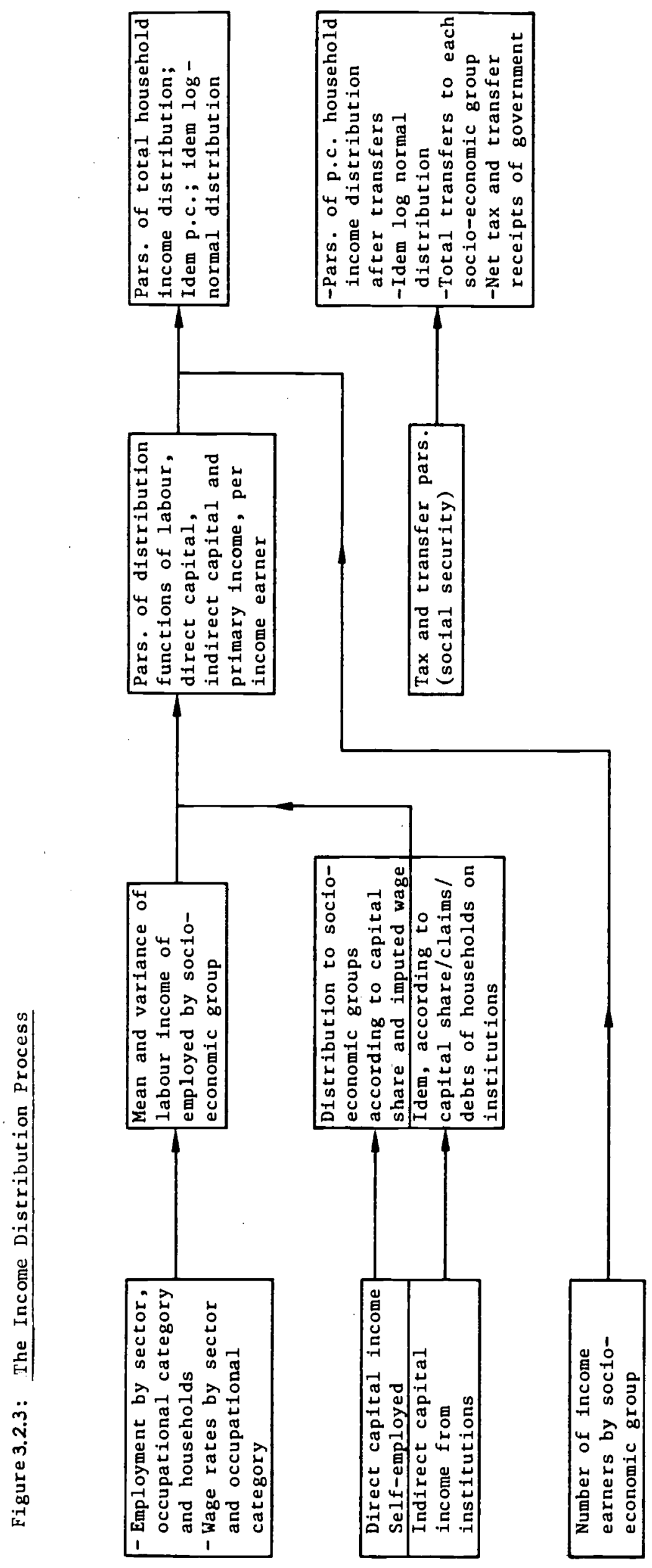


level no clear relationship with household income seems to exist because the risks covered by the social security are more or less evenly spread 17 (illness, unfitness, having chlldren etc.). The parameters of the secondary income distribution are expressed as:

$$
\begin{aligned}
& M\left(Y S C_{h}\right)=f\left(M\left(Y P C_{h}\right), S\left(Y P C_{h}\right), T O_{h}, T{ }_{h}\right) \\
& S\left(Y S C_{h}\right)=g\left(M\left(Y P C_{h}\right), S\left(Y P C_{h}\right), T O_{h}, T \alpha_{h}\right)
\end{aligned}
$$

where: $\mathrm{YSC}_{\mathrm{h}}$ per capita secondary or disposable household income

TO $h$ tax threshold or transfer celling

$T \alpha_{h}$ parameters of tax and transfer function

Government net tax receipts follow from the difference between the expected value of primary and secondary household income:

$T H_{h}=f\left(M\left(Y P C_{h}\right), S\left(Y P C_{h}\right), M\left(Y S C_{h}\right), S\left(Y S C_{h}\right), \dot{M}\left(H S_{h}\right), S\left(H S_{h}\right), C V_{h}(Y-S), H_{h}\right)$

where: $\mathrm{TH}_{\mathrm{h}}$ net tax recelpts from households $\mathrm{h}$

$\mathrm{H}_{\mathrm{h}} \quad$ number of households

Note that the expected value of household secondary income is not independent of the household size distribution; the parameters of the latter thus appear in eq. (3.2.23).

The derivation of the size distribution of per capita secondary income is shown schematically in figure 3.2 .3

A basic needs policy aims at increasing the productive employment and income of poor socio-economlc groups. Access-to-employment differentials (see eq. (3.2.13), and income disparities between socio-economic groups (see eq. (3.2.15)) are target parameters of, for example, educational policies. 


\subsubsection{Consumption}

This block determines the various components of the consumption demand of composite commodities as well as their domestic and foreign components. Household Consumption. Total per capita consumption expenditure is derived first by applying an iso-elastic total expenditure function to per capita disposable household income. Variables related to wealth are not included. 18 Consumption by commodity may be found in two stages: first, demand is derived for an aggregate consumption category, which is supposed to satisfy a certain basic or non-basic need; second, demand is calculated for the commodities which compose the consumption category. These aggregate consumption categories are defined so as to identify the various wants of households with regard to basic needs policies.

Total per capita household consumption is assumed to be a loglinear function of per capita disposable household income. Such specification retains lognormality:

$$
C C_{h}=f\left(Y S C_{h}, C \alpha_{h}\right)
$$

where: $\mathrm{CC}_{\mathrm{h}}$ total per capita household consumption

$$
\mathrm{C}_{\mathrm{h}} \text { parameters of consumption function }
$$

Per capita consumption per category also follows as a loglinear function, but now an additivity constraint has to be added to ensure that total consumption equals the sum of consumption of categories:

$$
\mathrm{CLC}_{\mathrm{hl}}^{*}=\mathrm{f}\left(\mathrm{CC}_{\mathrm{h}}, \mathrm{PL}_{1}, \omega_{\mathrm{hl}}, \zeta_{\mathrm{hl}}\right)
$$

where: $\mathrm{CLC}_{\mathrm{hl}}^{*} \quad$ uncorrected consumption of category 1

$$
\begin{array}{ll}
\mathrm{PL}_{1} & \text { price of aggregate consumption category } 1 \text {, a function of } \\
\text { prices of commodities: } P L_{1}=f\left(P_{1} \ldots, P_{K}\right) & (3.2 .26) \\
\omega_{h l}, \zeta_{h l} & \text { parameters, income and own price elasticities respectively }
\end{array}
$$

For the derivation of consumption of commodities (the second stage), the following steps are taken: 
(a) expected household consumption per category is calculated, taking into account the covariance with household size;

(b) total household consumption by category is calculated by summing-up over household groups;

(c) demand for consumption categories is mapped to demand for composite commodities by applying a transformation matrix, with typical element

$\left[\mathrm{TL}_{\mathrm{kl}}\right]$, such that:

$$
C K_{k}=\sum_{T L l} \cdot C L_{l}
$$

where: $\mathrm{CL}_{1}$ total consumption demand for category 1

$\mathrm{CK}_{k}$ total consumption demand for composite commodity $k$

In the end, the two stages together specify the consumption of commodities as function of total per capita household income and all commodity prices $\mathrm{P}_{\mathrm{K}}$ or, combining eq. $(3 \cdot 2.25-3 \cdot 2 \cdot 27)$ :

$$
C K_{k}=f\left(T L, C C_{1}, \ldots, C C_{H}, P_{1}, \ldots, P_{K}\right)
$$

where: $H, K$ number of household groups resp. commodities

The specification is such that all own (uncompensated) price derivatives are negative, whereas cross-price derivatives can be positive or negative: some pairs of goods are substitutes, others are complements.

Finally, the domestic and imported components of consumption demand for commodities are found from CES-import demand functions as first introduced by Armington (1969). Let $O$ be the CES-aggregation or composite commodity. Producers and consumers who buy domestically and import, will minimize costs; first order conditions lead to import and domestic shares as functions of relative prices:

$$
\begin{array}{ll}
\text { min.: } & P D_{k} D_{k}+P M_{k} M_{k} \\
\text { subject to: } & O_{k}=O_{k}\left(D_{k}, M_{k}\right)
\end{array}
$$




$$
\text { from which: } \quad \begin{aligned}
\mathrm{PD}_{\mathrm{k}} & =\partial O_{\mathrm{k}} / \partial \mathrm{D}_{\mathrm{k}} \\
\mathrm{PM}_{\mathrm{k}} & =\partial O_{\mathrm{k}} / \partial \mathrm{M}_{\mathrm{k}}
\end{aligned}
$$

where: $\partial O / \partial D, \partial O / \partial M$ first derivatives

Substituting $(3 \cdot 2 \cdot 29 b-c)$ into the composite price, defined as

$$
P_{k}=\left(P D_{k} D_{k}+P M_{k} M_{k}\right) / O_{k}
$$

leads to the dual price function:

$$
P_{k}=g\left(P D_{k}, P M_{k}\right)
$$

and $(3.2 .29 \mathrm{c})$ can be written as:

$$
(D / O)_{k}=d\left(P D_{k}, P M_{k}\right) ; \quad(M / O)_{k}=m_{k}\left(P D_{k}, P M_{k}\right)
$$

where: $\mathrm{PD}_{k}, \mathrm{PM}_{k}$ domestic and import price

$$
\begin{aligned}
& D_{k}, M_{k} \quad \text { domestic and import demand } \\
& P_{k}, O_{k} \quad \text { composite price, demand }
\end{aligned}
$$

This general specification of import demand covers all cases from fixed (volume) import shares to perfectly price elastic import demand. We feel justified in allowing for price responsiveness of imports. Tariff policies will act on relative prices, while direct import substitution policies will act on the parameters of the CES-function.

Combining $(3.2 .24),(3.2 .28)$ and $(3.2 .29 f)$, consumption demand for domestic commodity $k$ is found as a function of all incomes, all domestic prices and of the exchange rate (omitting all parameters):

$$
C K_{k}^{d}=f\left(X S C_{1} \ldots X S C_{H}, P D_{1} \ldots P D_{K}, E R\right)
$$


where: $\mathrm{CK}_{\mathrm{k}}^{\mathrm{d}}$ domestic component of consumption demand for commodity $\mathrm{k}$

Government Consumption. Government current expenditure consists of commodity consumption, wages and transfer payments. Interest payments are subsumed under net revenues from claims and debts of the government on/to other institutions and households. Mutatis mutandis this also holds for subsidies. Commodity consumption and part of salaries are considered as intermediate resp. primary inputs for the government sector which produces only the commodity "government services" bought by the public (a small part) and by the government itself (the bulk).

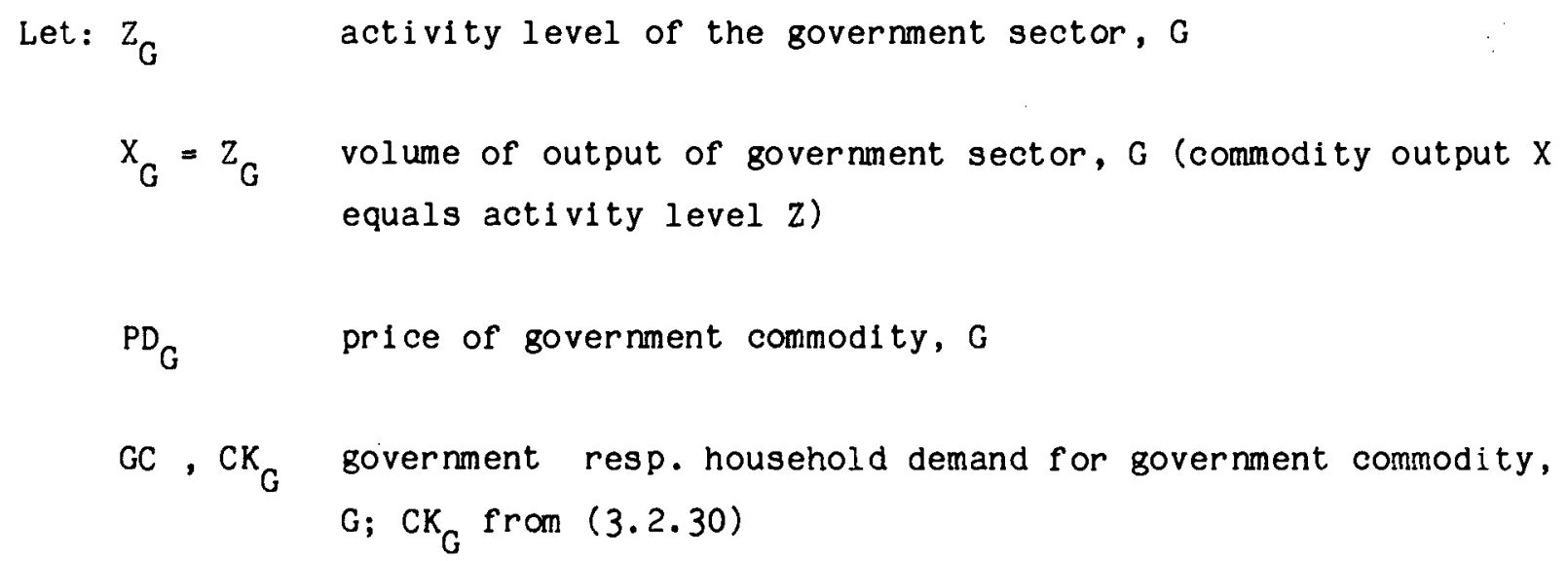

The volume of government demand for its services is determined by the lagged values of real government consumption and of real national income:

$$
G C=f(G D P,-1, G C)
$$

where: GDP real gross domestic product at factor prices

Total demand is assumed to determine government production:

$$
\mathrm{Z}_{\mathrm{G}}=\mathrm{X}_{\mathrm{G}}=\mathrm{CC}+\mathrm{CK}_{\mathrm{G}}
$$

The (imputed) price of government services is a Leontief aggregate of commodity prices $P_{k}$ and wage rates:

$$
P D_{G}=f\left(P_{1} \ldots P_{K},\left\{W_{S G}\right\}\right)
$$


where: $W_{S G}$ wage rate government by occupational category

Total government employment is taken as exogenous, and has already been fed into the employment allocation and rationing procedure of block 2 . Government activity-employment is directly related to output, wage payments being included in $P_{G} \cdot$ Given its activity level, the government demands composite intermediate inputs for the services it produces.

$$
\mathrm{GK}_{\mathrm{K}}=\mathrm{A}_{\mathrm{kG}} \cdot \mathrm{Z}_{\mathrm{G}}
$$

where: ${ }_{k G}$ input-output coefficient for sector government

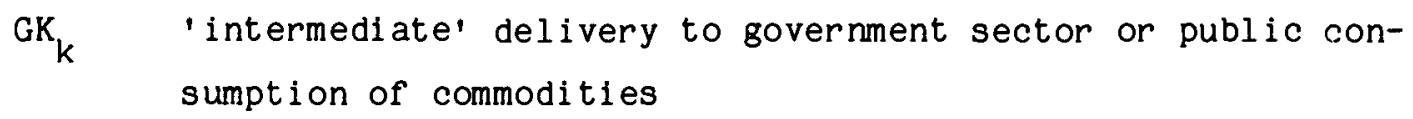

Part of these inputs are imported according to functions analogue to those specified for household consumption (see 3.2.29f).

Public services are distributed to the various types of services, i.e. education, health, infrastructure etc., where we assume exogenous proportions; furthermore, they are allocated to the benefitting household groups which have differential access to them. All types of services are assumed to have the same input structure and the same price. Access parameters are influenced by the distribution of income among socio-economic groups. The volume and value of imputed public consumption benefitting to households follows as:

$$
G C_{h_{g}}=f\left(G C, G_{h g}\right)
$$

where: $G C_{h g} \quad$ imputed consumption of service $g$ by household group $h$ GC volume of government services

${ }^{\mathrm{G}} \delta_{\mathrm{hg}}$ parameters reflecting the composition of government services ( $g$ ) and differential access ( $h$ ) 


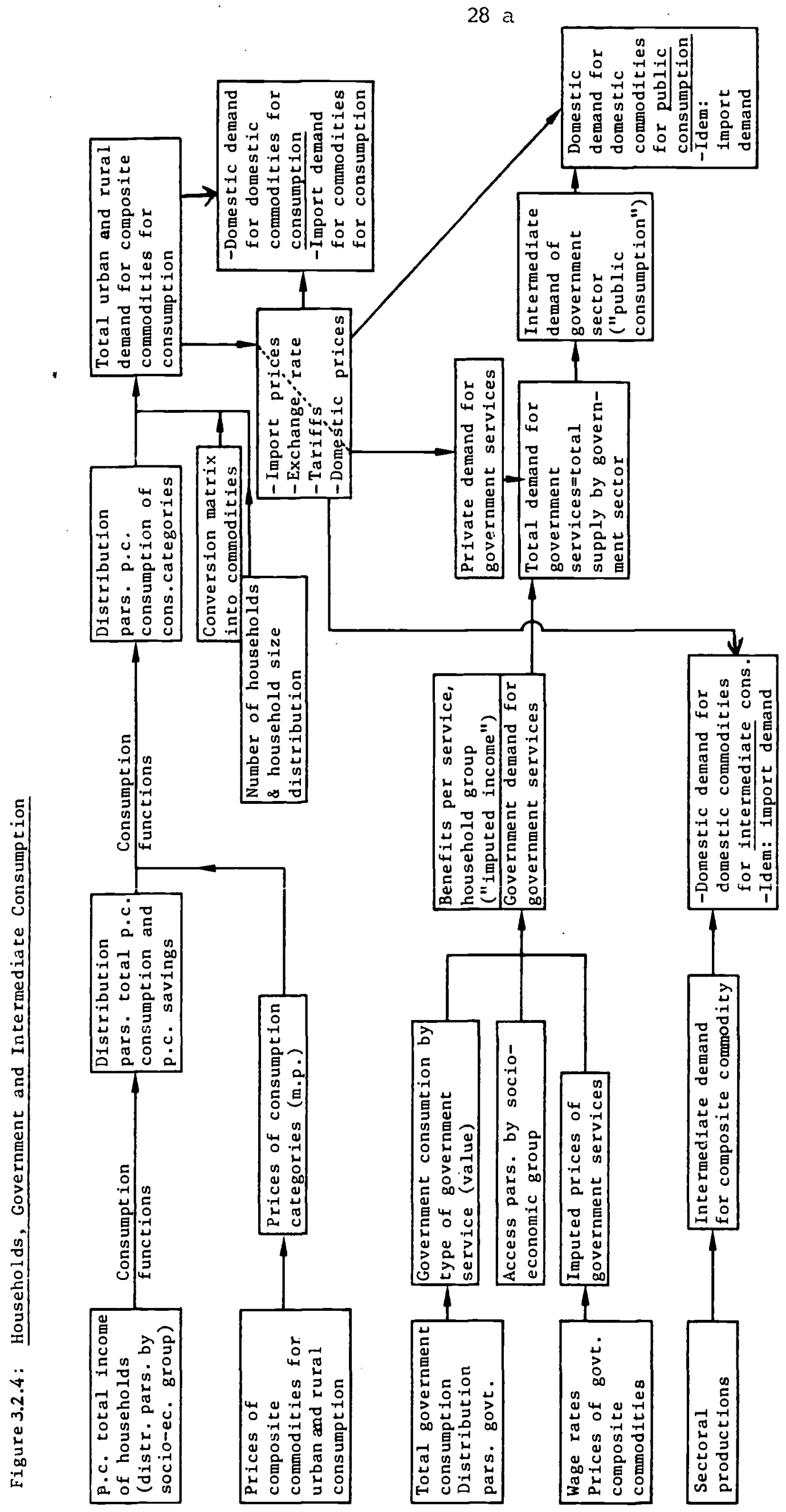


Intermediate consumption (non-government):

This type of demand is directly related to activity level Z (see equation (3.2.1 $\left.c^{\prime \prime}\right)$ ). Import dependence is again described by import demand functions of the form of eq. (3.2.29f). Note that the parameters of these CES-import functions differ among the various demand types (private, government, intermediate consumption). Intermediate consumption demand of the government sector is treated as a separate category in order to allow a differential trade policy: import functions of government intermediates are distinct from those of other sectors. Eq. (3.2.36) describes intermediate consumption of the composite commodity:

$$
V K_{k}=f\left(\left\{z_{n} \mid n \neq G\right\}, Z_{G}\right)
$$

where: $Z_{n}, n=1, \ldots, G, \ldots, N$ are sectoral activity levels

In figure 3.2.4 the consumption relationships are shown in schematic form.

\subsubsection{Flow of Funds and Investment}

Having determined income and total consumption of households in the previous block, household savings follow residually. The same holds for institutions (enterprises, etc.): profit income that is not paid as tax or distributed is saved. Government savings are identical to total revenue minus current expenditure, the former being the sum of the various tax sources, income from services sold to the public, net interest receipts on its claims (including royalties and other rents). Trade tax revenues net of subsidies are included. Gross foreign savings are taken as exogenous for the present presentation, but alternative specifications are explored.

Households and institutions are divided into surplus and deficit agents depending on whether they save more or less than the value of their own planned investment. Surplus agents channel their savings either directly to enterprises and the rest of the world (capital flight) in the form of shares, or indirectly through financial institutions in the form of bonds, bank deposits or other debt capital. 20

All allocations of funds are assumed to be proportional to the total of funds placed by the agents. This simplification has been introduced because 
portfolio theory does not seem to be applicable to the case of wealth-owners in a developing country, given the absence of fluid share and bond markets, the rigidity and government control of interest rates and the segmentation of credit markets.

Injections into the flow of funds system are possible through credit creation by banks. If no credit is created, each deficit agent takes the flows allocated to her and realises her planned investment up to an amount that equals the value of her own savings plus the total of these flows. In general, all deficit agents will desire a higher investment than this amount; i.e. a general excess demand for loanable funds will prevail in a country where real interest rates are kept below the equilibrium level. However, if an agent receives a higher ration than desired, the amount of this unused flow of funds is distributed proportionally to all credit receivers, whose realized investment will then rise with a uniform blow-up factor. Apart from this procedure which implies that savings determine investment, various other closure rules are introduced.

The approach as outlined has the following properties:

(a) savings basically determine investment at the macro-level, whereas credit injections from the banking system can be introduced to capture the phenomenon of forced savings;

(b) the market of loanable funds clears through rationing not through price adjustment;

(c) differential access to funds as well as differential cost of funds is accounted for, since each cell of a debt-claim matrix bears its typical remuneration rate;

(d) the current flow of funds represents the marginal change in the debtclaim structure which after updating, will determine future flows of indirect capital income;

(e) less attention is paid to desired investment. Due to the lack of a good investment theory and given the general lack of investable funds in the developing economy, this seems justified. 21 
The approach is summarised by:

$$
I R_{j}=f\left(S_{j}, I D_{j},\left\{\left(S_{j},-I D_{j},\right) \mid j \prime \neq j\right\}, I \alpha_{j j},\right)
$$

where: $s_{j}$

savings of agent $j$

$$
\begin{aligned}
& I R_{j}, I D \quad \text { realised and desired nominal investment agent } j \\
& \left\{\left(S_{j},-I D_{j}\right) \mid j \prime \neq j\right\} \text { savings of surplus institutions offered to the } \\
& \text { financial system } \\
& I_{j j} \text { distribution parameters of flow of funds }
\end{aligned}
$$

The value of investment per investing agent being known, the distribution among sectors of destination is derived as a function of profit rate differentials among sectors, the output growth and the original share of agent $j$ in the capital stock of sector $n$. No attempt is made to model intertemporal equilibrium, that is intertemporal clearing of capital markets, in view of theoretical and practical obstacles for doing so (cf. Dervis et al. (1982: 171-173). Instead, investment is entirely based on past realised values:

$$
I R_{n j}=f\left(I R_{j}, R_{n} / R_{j}, \Delta Z_{n}, \zeta_{n j}, \mu O_{j}\right)
$$

where: $\quad I_{n j}$ realised nominal investment, sector $n$, agent $j$

$R_{n} \quad$ sectoral profit rate of the previous period

$R_{j} \quad$ idem average profit rate of $j$, previous period

$\Delta Z_{n}$ absolute change in activity level of sector $n$

$\zeta_{n j}$ sector $n$ share in capital stock of $j$

Ho $j$ capital mobility parameter 
Mobility parameters of zero imply that sectoral investment shares are fixed; on the other hand, high mobility parameters will make capital respond quickly to profit rate differentials such that, ceteris paribus, the capacity increase in the next period will reduce the rent on the fixed factor capital in that high profit sector. The absolute output change of a sector reflects the traditional flexible accelerator, which is especially relevant for agricultural investment by households.

It should be noted that additivity constraints will always have to be satisfied, such that the sum of sectoral investments equals total investment (per agent). The volume of investment by sector of destination follows from deflation by the composite price of the heterogeneous capital good of a sector:

$$
\begin{aligned}
& R I R_{n j}=I R_{n j} / P K_{n j} \\
& P K_{n j}=f\left(B_{k n j}, P_{k}\right)
\end{aligned}
$$

where: $\quad R_{n j}$ volume of investment

$$
\begin{aligned}
& \mathrm{PK}_{n j} \quad \text { price of composite investment good } \\
& \mathrm{B}_{\mathrm{knj}} \quad \begin{array}{l}
\text { capital coefficients, } k, n, j \text { referring to commodity of } \\
\text { origin, sector of destination and investing agent }
\end{array} \\
& \mathrm{P}_{k} \quad \text { composite price of commodity } k
\end{aligned}
$$

From eq. (3.2.38a-b) follows the demand for composite investment commodities as:

$$
I K_{k}=\sum_{n, j} B_{k n j} R_{n j}
$$

Finally, the imported and domestic components of $I K_{k}$ are derived similarly to the import functions for consumption (see eq. (3.2.29f)).

As with intermediate demand, government demand for investment commodities is treated separately in order that differentiated trade policies 


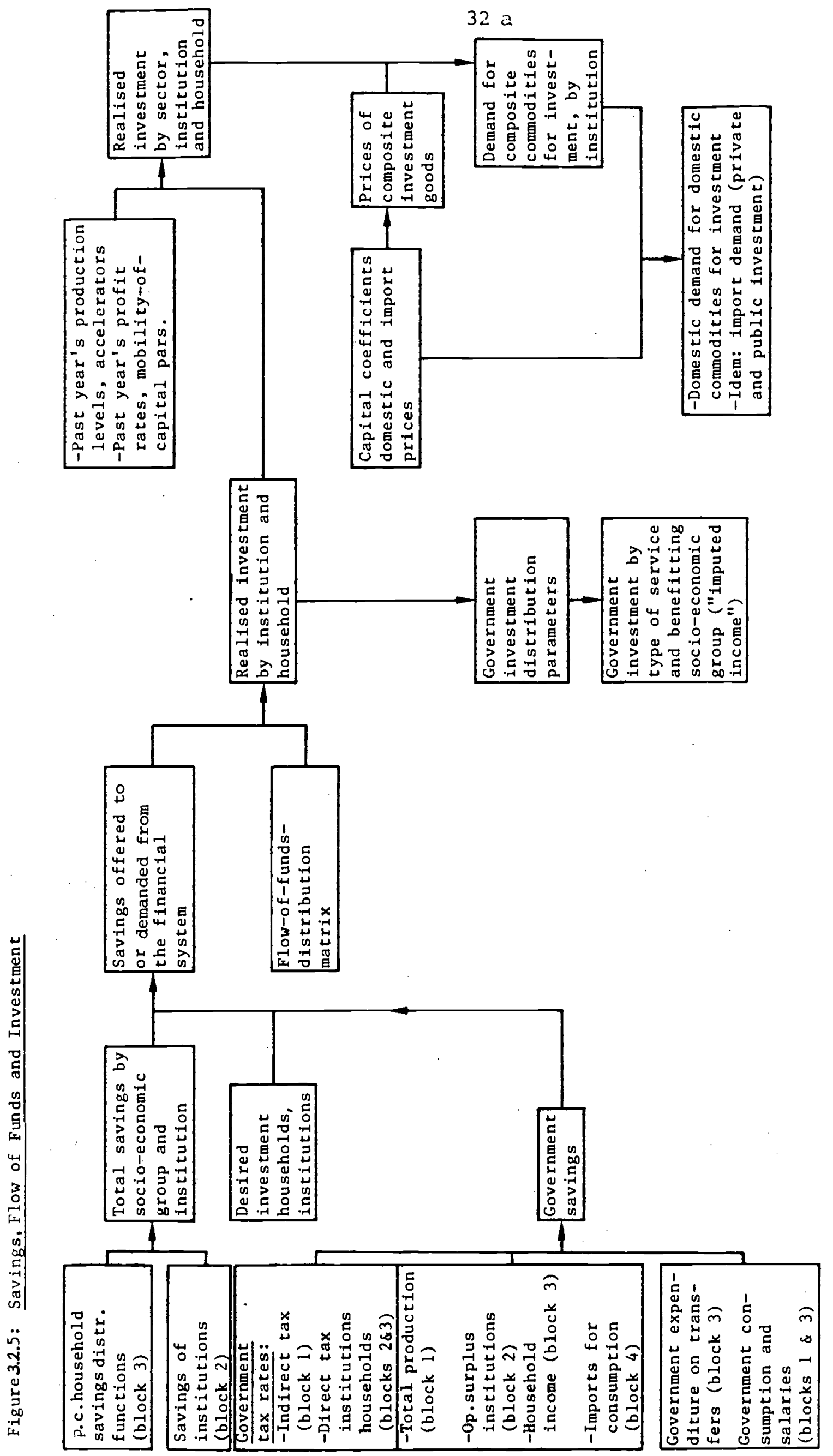


may be modelled. Investment by the government sector $1 \mathrm{~s}$ subdivided by type of government service and by benefitting household group.

Let $\mathrm{RIR}_{\mathrm{GG}}$ be realised investment by the government in the sector government; then :

$$
\mathrm{GI}_{\mathrm{hg}}=\mathrm{f}\left(\mathrm{RIR}_{\mathrm{GG}}, \mathrm{G}_{\mathrm{h}}\right)
$$

where: $\mathrm{GI}_{\mathrm{hg}}$ real government investment by type of service, $g$, and benefitting household, $h$

$\mathrm{Gk}_{\mathrm{hg}}$ parameters for differential access to each type of investment

From this imputed household investment one can derive a proxy of the value of capital consumption of public infrastructure. ${ }^{22}$ Figure 3.2 .5 shows the scheme for the savings-investment block. 23

\subsubsection{Exports and Excess Demand}

Demand for export is dependent on foreign income and on the country's competitiveness as described by relative prices:

$$
E D_{k}=f\left(\bar{E} \bar{W}, \bar{P} \bar{W}_{k} / P E_{k}\right)
$$

where: $E D_{k} \quad$ foreign demand

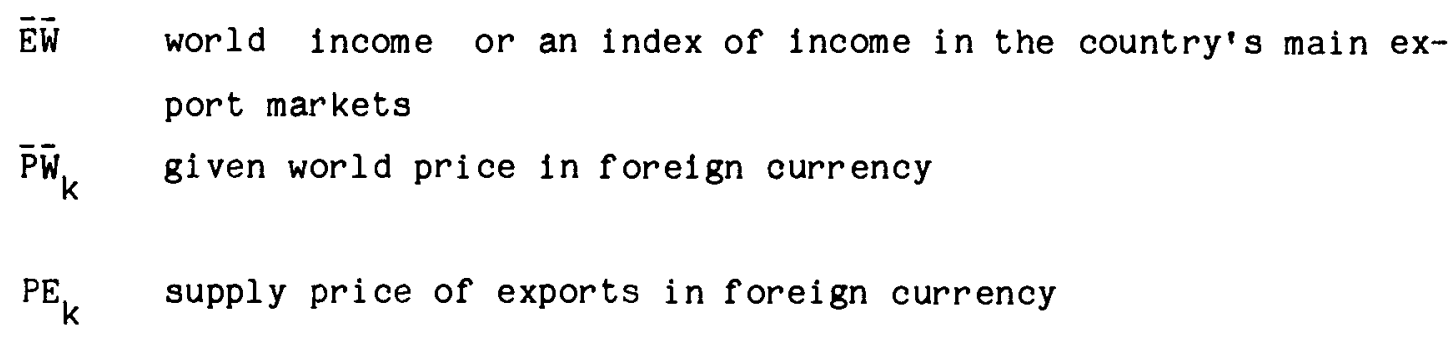

A specific export supply function is only relevant if the price in domestic currency that domestic producers receive for exports differs from that they receive on the home market. In this case, export markets are cleared separately and a number of endogenous (export) price variables are added to the model. This refers to the case of price discrimination which is 
relevant when export targets are imposed domestically or abroad. In the other case, prices are uniform across domestic and forelgn markets and total (domestic plus foreign) demand is confronted with domestic supply. In the first case export supply functions are specified: 24

$$
E S_{k}=f\left(X_{k}, P F D_{k} / P F_{k}\right)
$$

where: $E S_{k} \quad$ supply of exports

$$
\begin{aligned}
& \mathrm{X}_{\mathrm{k}} \quad \text { production of commodity } \mathrm{k} \\
& \mathrm{PF}_{\mathrm{k}} \quad \text { price of exports producers receive, in domestic currency } \\
& \mathrm{PFD}_{\mathrm{k}} \quad \text { average price of domestic sales and exports }
\end{aligned}
$$

For example, the supply is a CES-aggregate of supply to domestic and foreign markets. The price of commodity $k$ which is relevant to the production decision (see eq. (3.2.3)) will then be a composite price:

$P F D_{k}=f\left(P D_{k}, P F_{k}\right) \quad$ which includes the case where export targets are imposed, i.e.: $E_{k}=\bar{E} \bar{S}_{k}$. Export tax and exchange rate determine the relation between export price in domestic and foreign currency:

$$
P E_{k}=P F_{k}\left(1+t e_{k}\right) / E R
$$

where: $t e_{k}, E R_{k}$ export tax and exchange rate

Equations (3.2.40-3.2.42) and the equilibrium condition $E D_{k}=E S_{k}$ determine equilibrium prices and exports.

In the second case, equation (3.2.41) is dropped since no specific export supply behaviour will exist when price differentiation is excluded; in fact, the substitution elasticity of (3.2.41) is set equal to infinite and (3.2.41) is replaced by:

$$
P F_{k}=P D_{k}
$$


while export demand is added to the various components of domestic demand to be confronted with domestic supply. For equilibrium domestic prices, $P D_{K}$, domestic demand $p l u s$ foreign demand at foreign prices, $P E_{k}$, from $(3.2 .411)$ and (3.2.42) will equal supply $x_{k}$.

A special but sometimes relevant case of (3.2.40) occurs when the price elasticity of world demand is infinite, i.e. World prices are given and the country can sell any amount it wants at prices:

$$
P E_{k}=\bar{P}_{k}
$$

In such case domestic prices are determined from outside through (3.2.40'), $\left(3.2 .41^{\prime}\right)$ and $(3.2 .42)$ :

$$
P D_{k}=\bar{P}_{k} E R /\left(1+t e_{k}\right)
$$

and the excess supply, after domestic demand has been met, is exported.

Cases with and without price discrimination are both included in the model, depending on the commodity.

\section{Excess Demand}

Adding up all demand components for the domestic commodity from blocks 4-6 and taking domestic supply from block 1,25 we derive excess demand functions:

$$
E X C_{k}=\Sigma_{f} D_{k f}-X_{k}=f\left(\left\{P D_{k}\right\}, E R\right)
$$

where: $D_{k f}$ domestic component of demand type $f$ for commodity $k$, where $f$ includes: consumption (private, government, intermediate), investment and export

$$
x_{k} \quad \text { domestic supply }
$$

which appears as a function of all domestic prices and the exchange rate. ${ }^{26}$ These equations are the basis on which to determine the iterative price adjustment process. Excess demand for foreign exchange is determined from the 
sum of exports and imports, the latter following from the import demand functions in blocks 4 and 5 , and other components of the balance of payments :

$$
\mathrm{EXC}_{K+1}=\mathrm{f}\left(\left\{\mathrm{PD}_{k}\right\}, \mathrm{ER}\right)
$$

Those other components are:

(a) net factor income, determined in block 2 as a function of foreign factor ownership (the 'rest of the world' being one of the institutions which own factors);

(b) net transfers from abroad (exogenous);

(c) gross foreign savings (exogenous or endogenous, depending on the closing rule);

(d) capital flight, determined in the flow of funds matrix of block 5 as a function of domestic savings.

Taxes on imported investment goods and exports are derived from the value of those imports and exports; since other government revenue was already determined in block 4, these taxes form the only source of income which did not lead to expenditure in a previous equation: All other incomes are channelled into some kind of demand and Walras' Law holds except for these trade taxes, or the value sum of excess demands equals zero:

$$
\varepsilon=\sum_{k}^{K+1} \quad{ }^{E X C} C_{k} \quad P D_{k}=0
$$

where: $P D_{K+1}=E R$ exchange rate

The trade taxes just mentioned cause a negative total excess demand $(\varepsilon<0)$. By adding the value of these trade taxes to government revenue of the next iteration the value of excess demand will fall because under normal circumstances, the change in these trade taxes from one iteration to the next will approach zero.

The iterative process works as follows:

(a) take an initial price vector, $\mathrm{PD}_{k}$, and go through blocks 1-6 to determine supply and demand;

(b) determine excess demand and define a new price vector: 
30 a

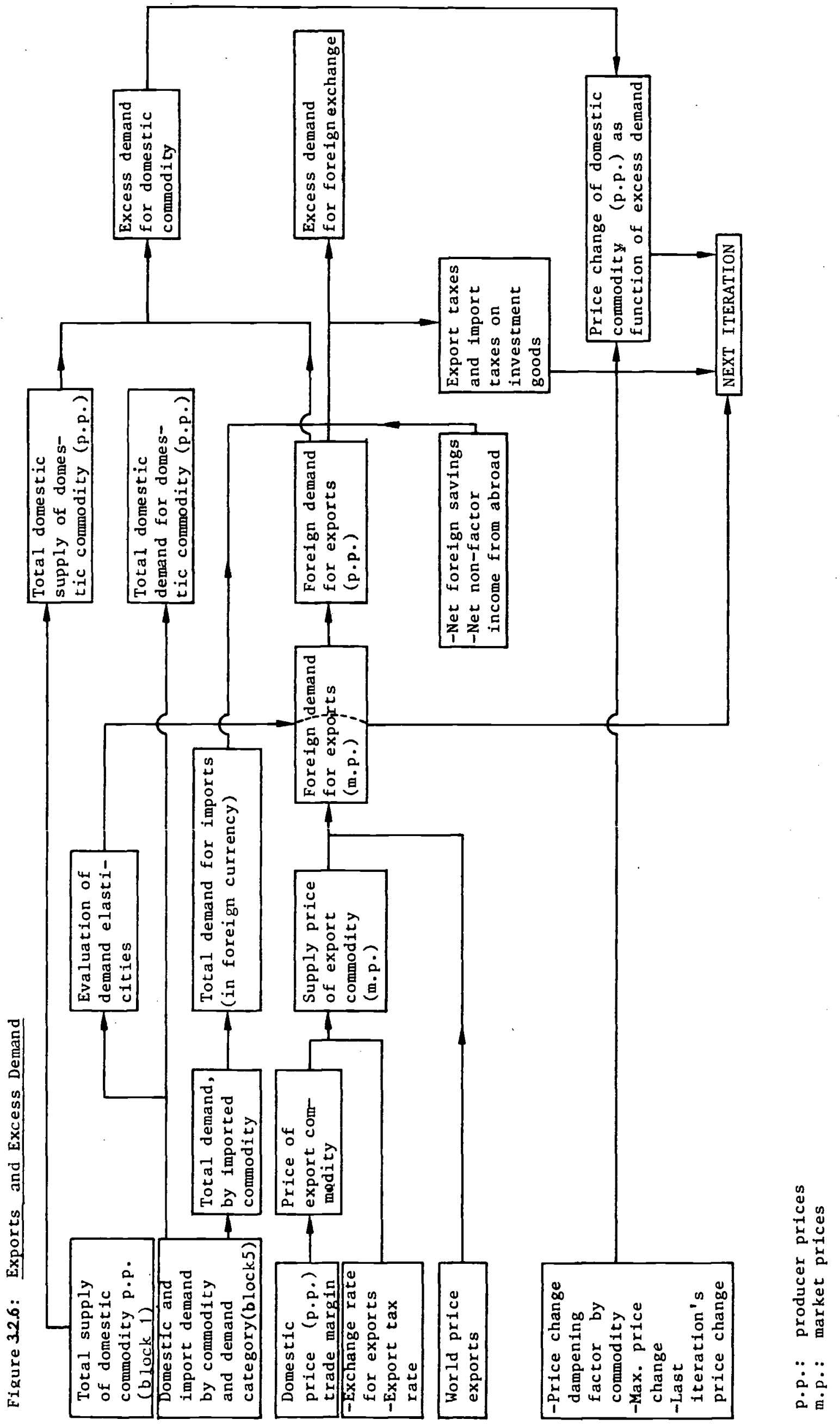




$$
P D_{k}^{\prime}=P D_{k}+f\left(E X C_{k}, X_{k}\right)
$$

where: $P D_{k}^{\prime}$ price for next iteration

(c) continue until convergence is reached.

The price change function is such as to set certain limitations to price changes between two iterations in order to prevent too high price changes and al ternating.

A scheme of block 6 is found in figure 3.2.6, while the solution method actually used is dealt with in more detail in section 3.3 below.

\subsubsection{Updating Population and Labour Supply}

In this block an exogenous overall population growth is distributed among urban and rural zones on the basis of urban-rural wage differentials, differential access to government services, and propensity to migrate. This is a simplified version of the Harris-Todaro migration model in which the $r i s k$ of unemployment is implicit since the average per capita disposable and imputed household income is taken to describe the incentive for migration:

$$
\begin{aligned}
& \text { MUR }=f\left(Y S C_{u}, Y S C_{r}, G C_{u}, G C_{r}, \mu l\right) \\
& g_{u}=g_{u}(g, M U R) \\
& g_{r}=g_{r}(g, M U R)
\end{aligned}
$$

where: $g_{u}, g_{r}, g$ growth rate population total, urban, and rural

MUR number of persons that migrate to urban areas

H. propensity to migrate

YSC $_{u}, Y S C_{r}$ average p.c. disposable household income, urban and rural

$\mathrm{GC}_{\mathrm{u}}, \mathrm{GC}_{\mathrm{r}} \quad$ imputed benefits government services, urban and rural 
The exogeneity of overall population growth is one alternative in the model; the other option incorporates the effects of baslc needs satisfaction on fertility and mortality.

The distribution of urban population among household groups, characterized by the level of education of the household head, depends on the output from the educational system as well as on the composition of persons by educational level of each household group.

Let: ${ }^{C} C_{\text {he }}$ government expenditure on education of type e, benefitting to households $\mathrm{h}, \mathrm{h} e \mathrm{H}^{\mathrm{u}}$ (set of urban household groups)

EY set of parameters that describe the efficiency of the educational system (costs per pupil, retention rates, etc.)

Then the change in the number of persons with educational level $e$ is:

$$
\Delta P O_{e}=f\left(\left\{G C_{h e}, E \gamma_{e}, M O R_{e}\right\}\right)
$$

where: $\mathrm{PO}_{e}$ the number of urban persons with educational level $e$

$$
\text { MOR e mortality rate educational level e }
$$

The number of education types equals the number of urban socio-economic groups - education of the household head being the classification criterion. [E] is defined as a matrix of which the typical element is the average number of persons with education of type e per household of type $h$. We thus assume a fixed educational composition of the population of a socio-economic group; as education improves, people will move to a higher group (in terms of educational level of the household head). We have:

$$
\begin{aligned}
& P O_{e}=\sum_{h} E_{e h} P O_{h} \\
& P O_{h}=\sum E_{h e}^{-1} P O_{e}
\end{aligned}
$$

where: $\mathrm{PO}_{\mathrm{h}}$ number of persons in urban household group $\mathrm{h}$ 
$\left[E_{h e}^{-1}\right]$ element of inverse of $[E]$

The parameters of the (lognormal) distribution of household size are a function of the logmean of per capita household income, intended to reflect the lower propensity of people to live in one household as per capita income rises:

$$
\begin{aligned}
& M\left(H S_{h}\right)=f\left(M\left(Y S C_{h}\right)\right) \\
& S\left(H S_{h}\right)=g\left(M\left(Y S C_{h}\right)\right)
\end{aligned}
$$

where: $M\left(\mathrm{HS}_{h}\right), \mathrm{S}\left(\mathrm{HS}_{h}\right)$ logmean, logvariance of household size

$$
M\left(Y_{h C}\right), S\left(Y S C_{h}\right) \text { logmean, logvariance p.c. disposable household income }
$$

From (3.2.50) and (3.2.51) follows the number of households:

$$
H_{h}=P O_{h}^{\prime} A\left(H S_{h}\right)
$$

where: $A\left(H_{h}\right)$ average household size

$$
\mathrm{H}_{\mathrm{h}} \quad \text { number of households of type } \mathrm{h}
$$

The number of agricultural households, grouped into four size classes of 1 and owned, is changed exogenously. ${ }^{27}$ The number of persons depends on the endogenous household size distribution of eq. (3.2.51):

$$
P O_{h}=H_{h} \quad A\left(H_{h}\right)
$$

The educational composition of each of the rural groups depends on access to the educational system:

$$
P O_{h e}=f\left(P O_{h}, E Y_{e}, G C_{h e}, M O R_{e}\right)
$$

where: $\mathrm{PO}_{\text {he }}$ population with educational level $\mathrm{e}$ in group $\mathrm{h}$ 
Both the number of economically active persons and that of income earners is determined according to a binomial distribution where the average probability of being economically active or an income earner ${ }^{28}$ is a function of household size leading to:

$$
\begin{aligned}
& A\left(\mathrm{~N}_{h}\right)=f\left(M\left(\mathrm{HS}_{h}\right), S\left(\mathrm{HS}_{h}\right)\right) \\
& A\left(\mathrm{LH}_{h}\right)=g\left(M\left(\mathrm{HS}_{h}\right), S\left(\mathrm{HS}_{h}\right)\right)
\end{aligned}
$$

where: $A\left(N_{h}\right), A\left(L_{h}\right)$ average number of income earners resp. economically active persons per household in group $h$

Finally, labour supplied by household groups follows from:

$$
L H_{h s}=f\left(L H_{h}, P O_{h e}, L \lambda_{h s},\left\{\sum_{h n} L_{s I_{s}}-L s_{s}\right\}, W_{s}\right)
$$

where: $\mathrm{LH}_{\mathrm{hs}} \quad$ labour supply of occupational category $\mathrm{s}$, household group $\mathrm{h}$ $\mathrm{L} \lambda_{h s}$ set of parameters describing responsiveness of supply to excess demand and wage differentials for each occupational category, where excess demand refers to the past period

$\sum_{n} L_{s n}, L_{s}, L S_{s}$ wage labour demand, selfemployment and labour supply, by occupational category $s$

Wage rates adjust partially to excess demand for labour of a certain occupational category. The response is supposed to be uniform for all sectors, thus maintaining sectoral wage disparities:

$$
W_{s n}^{\prime}=f\left(W_{s n},\left(\sum_{S} L_{s n}+L I_{s}-L S_{s}\right), L \gamma_{s}, P C\right)
$$

where

$$
\begin{array}{ll}
W_{\text {sn }} & \text { new wage rate } \\
L \gamma_{s} & \text { response parameter to excess demand } \\
P C & \text { consumer price index }
\end{array}
$$




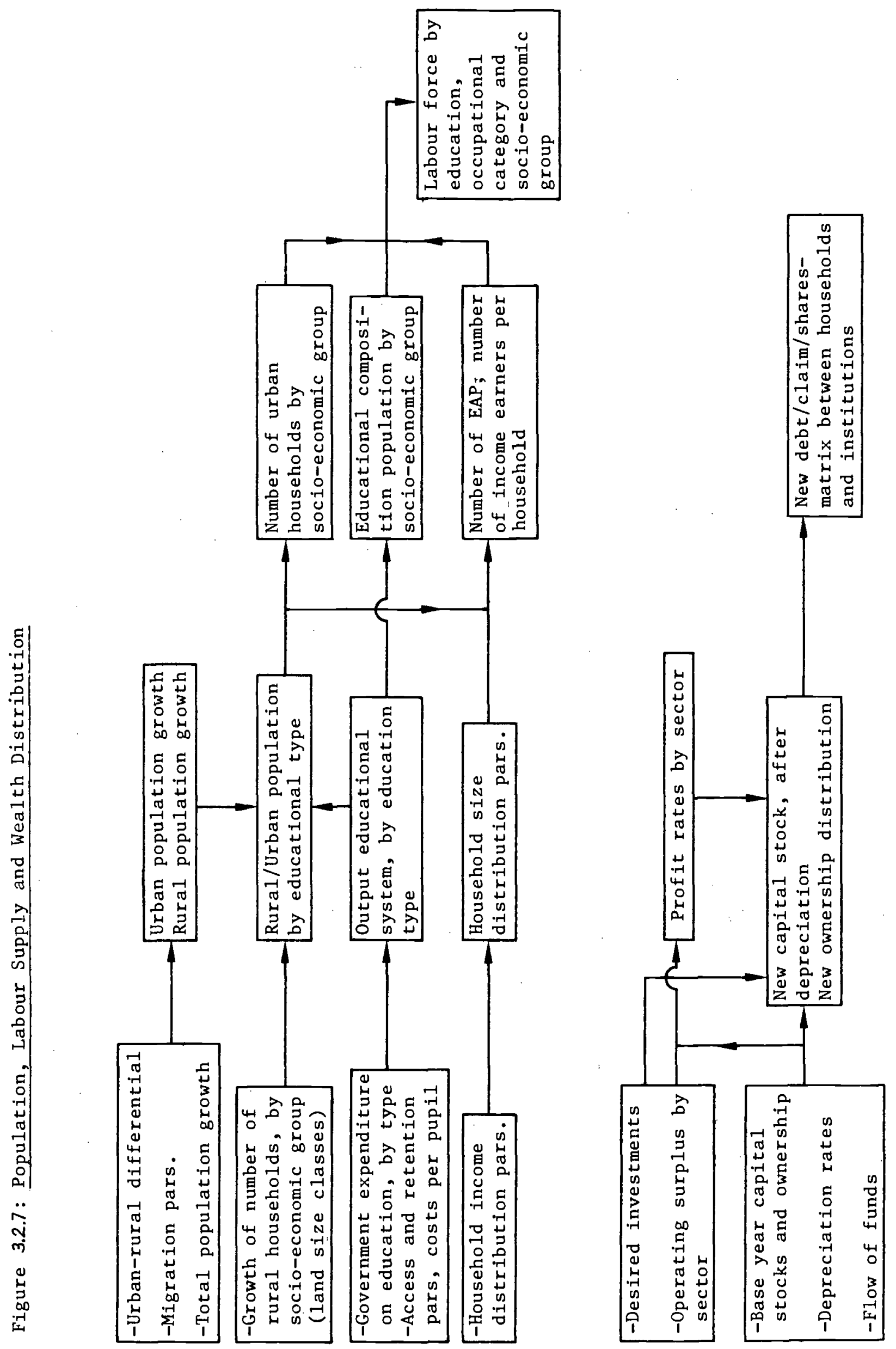


It is clear that a policy orlented towards fulfillment of the basic need for education will affect the labour supply through equations (3.2.50-3.2.56). A schematic presentation of the updating blocks for population and labour supply is given in figure 3.2 .7 .

\subsubsection{Updating Capital Stocks and Ownership}

Sectoral capital stocks are modified through depreciation and investment:

$$
K_{n}=-1 K_{n}\left(1-\delta \pi_{n}\right)+\sum_{j} R I R_{n j}
$$

where: $K_{n} \quad$ sectoral capital stock

$$
\begin{aligned}
& \delta \pi_{n} \quad \text { sectoral depreciation rate } \\
& R I R_{n j} \text { volume of investment in sector } n \text { by agent } j
\end{aligned}
$$

With equation (3.2.58), current year investments $R I R_{n j}$ and current year prices of composite capital goods, $\mathrm{PK}_{n j}$, each agent's direct share in sectoral capital stocks is updated. For example, when self-employed households invest in livestock they increase their share of the future gross operating surplus of that sector. Profit rates on capital stock of the past year are found from the operating surplus minus imputed wage of self-employed and net of depreciation:

$$
R_{n}=\left(P N_{n} Z_{n}-\left(L_{n}^{a}+L I_{n}\right) w_{n}\right) /\left(-1 P K_{n}-1 K_{n}\right)-\delta \pi_{n}
$$

where: the numerator denotes gross operating surplus after imputed wage income of self-employed

$\mathrm{PK}_{\mathrm{n}}$ price of capital stock $\mathrm{n}$ ( -1 : one year $\left.1 \mathrm{ag}\right)$

Profit rate differentials affect the sectoral allocation of investment, as has been seen in equation (3.2.37b). A schematic presentation of the updating block for capital is given in figure 3.2.8. 


\subsubsection{Basic Needs Indicators}

Solutions for income and consumption variables of the main part are fed into the basic needs block in order to derive basic needs indicators:

$$
\mathrm{BNI}_{h g}=\mathrm{f}\left(\mathrm{M}_{\mathrm{h}}\left(\mathrm{CLC}_{h l}\right), \mathrm{S}\left(\mathrm{CLC}_{\mathrm{hl}}\right), \mathrm{GC}_{\mathrm{hg}}, \mathrm{EY}_{\mathrm{g}}\right)
$$

where: $\mathrm{BNI}_{\mathrm{hg}} \quad$ basic needs indicator of type $\mathrm{g}$ for group $\mathrm{h}$

$$
\begin{aligned}
& M\left(C L C_{h}\right), S\left(C L C_{h}\right) \text { logmean and logvariance of per capita household con- } \\
& \text { sumption of category } 1 \\
& \mathrm{GC}_{\mathrm{hg}} \quad \text { consumption of government service } \mathrm{g} \text { by group } \mathrm{h} \\
& { }^{E} \gamma_{g} \quad \text { parameters reflecting the efficiency of government } \\
& \text { expenditure in terms of basic needs satisfaction }
\end{aligned}
$$

The basic needs indicators refer to calorie consumption, consumption of other basic categories (incl. "consumption" of housing, whether in monetary or in imputed form, i.e. own housing), as well as to access to public services such as drinking water, sewerage, health facilities, public housing programmes, etc. Indicators for private consumption of certain essential categories can be derived directly from the parameters of the distribution functions of block 4; for example, the fraction of persons who consume less than a minimum quantity of a category. ${ }^{29}$ Indicators of public consumption are determined by the volume and efficiency of various government services, as well as by the access of socio-economic groups to them.

Specific indicators $\mathrm{BNI}_{\mathrm{hg}}$ are combined into weighted overall indicators

$$
\mathrm{BN}_{\mathrm{h}}=\mathrm{f}\left(\left\{\mathrm{BNI}_{\mathrm{hg}}\right\}\right)
$$

Given a specific basket of basic needs consumption categories which defines the minimum quantities needed to reach a level considered as 'basic!, the current value of that basket can be recalculated with the set of prices of the main part. With the Engel coefficient with respect to total consumption of those basic categories, a basic needs threshold income may be found. The 


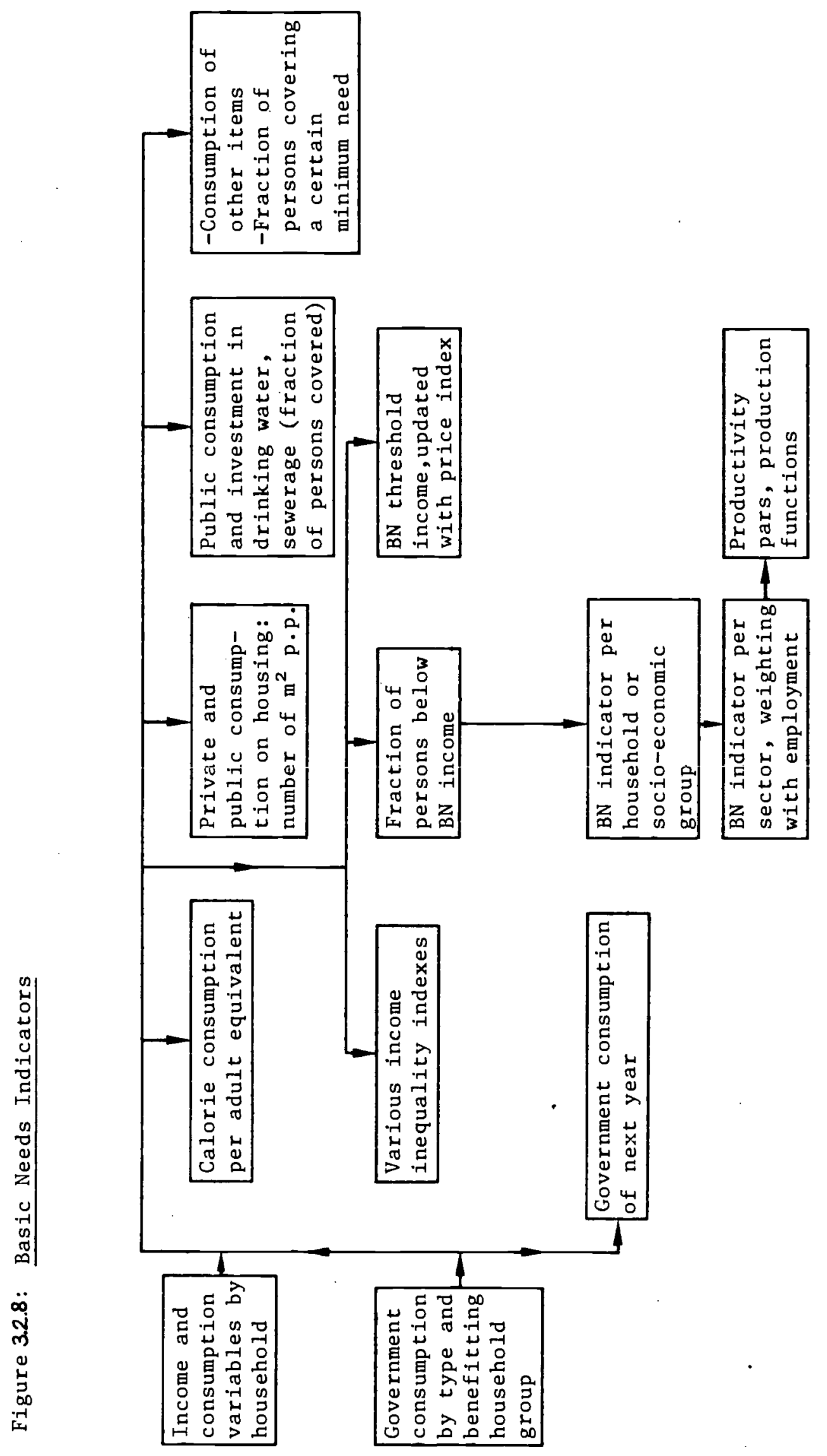


number of households below that threshold follows from the parameters of the per capita household income distribution :

$$
\mathrm{HBN}_{\mathrm{h}}=\mathrm{f}\left(\left\{\mathrm{PL}_{1}\right\},\left\{\Psi_{1}\right\}, M\left(Y S C_{h}\right), \mathrm{S}\left(\mathrm{YSC}_{\mathrm{h}}\right)\right)
$$

where: $\mathrm{HBN}_{\mathrm{h}}$ number. of households with per capita household income below the 'basic needs threshold income'

$M\left(Y S C_{h}\right), S\left(Y S C_{h}\right)$ parameters distribution p.c. disposable household income

$\mathrm{PL}_{1} \quad$ prices of consumption category 1

$\Psi_{1} \quad$ shares of categories in 'basic' basket

Income inequality indices by household group are directly derived from the parameters of the household income distribution. Income inequality indices are also calculated from the parameters of household income distribution as well as an "overall" inequality index. Since they can be decomposed by classification factors such as occupational category, as well as by additive factors such as wage income, capital income etc., the overall inequality index can be decomposed by household group and the factors just mentioned. Given the proposed lognormality of income distribution, the logvariance has particularly useful properties in this respect.

Finally, the longer-term effects of satisfaction of basic needs on sectoral productivities is taken into account by adjusting the relevant parameters of the production functions:

$$
\left.\gamma_{n}=f\left(\left\{B N I_{n g}\right\}\right),\left\{B \gamma_{n g}\right\}\right)
$$

where $:{ }_{n}^{\gamma} \quad$ prodptivity parameter sector $n$

${ }^{B} Y_{n g}$ set of parameters that determine the effect on productivity in sector $n$ of basic needs satisfaction of type $g$

In figure 3.2.8 the basic needs block is shown in schematic form. 


\subsection{Solution and use of the model}

\subsubsection{Solution method: tâtonnement}

The problem of solving the model can be formulated in terms of a set of excess demand functions for which an equilibrium price vector should be found. Excess demand were derived in eq. (3.2.44-3.2.45), where Walras' Law was mentioned which $1 \mathrm{mplies}$ that one of $K+1$ excess demand equations ( $K$ commodities, foreign exchange) is dependent (see also table 3.3.1 and the preliminary discüsion in section 3.1). Walras' Law is written as:

$$
\sum_{k=1}^{K+1} E X C_{k}=\sum_{k=1}^{K+1} f_{k}\left(P D_{1}, \ldots, P_{K}, E R\right)=0
$$

where: ER refers to the price on the market for foreign exchange

Referring (3.3.1) two remarks are in order: on Walras' Law and on homogeneity of the excess demand functions, both related to the issue of the numeraire. Walras' $\mathrm{Law}^{30}$ implies that one excess demand equation is dependent, so that only. $K$ prices can be determined. One price can be $f i x e d$ or, more generally, a linear equation in prices $\pi\left(P D_{1}, \ldots, P D_{K}, E R\right)=0$ may be set to determine the $(K+1)$ th price. The choice of this price equation brings us to the homogeneity-of-degree-zero property implying:

$$
f_{k}(\lambda p d)=\lambda \cdot f \cdot(p d) \text { for } k=1 \ldots k+1 \text {, pd vector of prices }
$$

Homogeneity is useful in proving the existence of a solution, but not a necessary condition. 31

Homogeneity. In a system, homogeneous of degree zero, only relative prices matter; one of the excess demand equations can be dropped and replaced by $a$ price-normalisation rule, for example, $P_{1}=0$ or $\sum_{k} \omega_{k} P D_{k}=\bar{P} \bar{D}$. The choice of normalisation rule (numeraire) does not affect the outcomes for real variables. When the system is not homogeneous of degree zero, the choice of numeraire may affect the solution in real terms. In its general formulation our model is not homogeneous of degree zero; in particular, when excess money creation is allowed and corresponding demand functions for nominal balances are introduced, then money is not neutral, the absolute price level is determined and af ects real variables. Even when money demand and supply 
are left out from the model, ${ }^{32}$ non-homogeneity occurs in a number of specifications:

- household consumption functions are not invariant to a uniform increase in all prices;

- the same holds for functions for institutions' tax, transfer, savings and government consumption;

- hence investment is not invariant to a uniform increase in all prices;

- wages and interest rates are fixed in nominal terms, implying shifts in income distribution when all prices move with the same factor.

We could have altered these specifications and ensured homogeneity by fixing intercepts and wages in real terms etc. or by specifying how taxes and transfers are compensated for price changes. ${ }^{33}$ This was not done because we trusted the functions as they were estimated, displaying some, but not large, non-homogeneity. Inspection of parameter values of functional forms indicated that the impact of the general price level, when real wages and interest are kept constant, is probably very small. Moverover, nonhomogeneity is to be accepted for non-money-neutral versions anyway. In money-neutral versions of the model, wages were kept fixed in nominal terms in the main, current-year part, because a simultaneous adjustment was felt to be unrealistic; rather, wages should adjust to a change in the general price level with some lag: we applied such indexation in the updating part. Practically speaking, we could always find solutions for the non-homogeneous model, solutions which did not depend on start values of the prices. 34

We now motivate our choice of num'raire: the exchange rate in most of the runs.

Choice of numeraire. In trade models that distinguish tradable from nontradable goods, ${ }^{35}$ the relative price between the two can be interpreted as the real exchange rate. In a flexible specification where both export demand and import demand functions are less than infinitely price elastic, the distinction looses its straight-forward meaning. One would write the real exchange rate (RER), by splitting (some what arbitrarily) the domestic commodities into more ("MT") and less ("LT") tradables, i.e.:

$$
\text { RER }=\frac{\sum_{L T}^{M T}{ }_{k}^{\omega_{k} P D_{k}}}{\omega_{k} \overline{P D}_{k}}=\frac{\sum{ }_{L T} \omega_{k} \overline{P W}_{k} \quad \text { ER }}{\omega_{k} \overline{P D}_{k}}
$$


where: $\quad \omega_{k}$ appropriate weights

the last equality refers to the special case that world prices determine prices of tradables and ER is the nominal exchange

In choosing a normalisation rule one might give weight to a ready interpretable form of the real exchange rate. For instance, normal isation around the general price level:

$$
\sum_{k} \omega_{k} P_{k}=\bar{P}
$$

where: $\quad P_{k}=f\left(\overline{P W}_{k}, E R, P_{k}\right) \quad$ composite price

leads to a real exchange rate which is more difficult to interpret directly. We took the traded goods universe to be broader than actual exports and imports, i.e. in principle all domestic commodoties compete with foreign ones; considering all commodities as more or less tradable, we defined the real exchange rate as:

$$
\operatorname{RER}=\frac{\sum \Omega_{k} \bar{P}_{k} E R}{\sum_{k} \Omega_{k}^{*}{ }^{*} D_{k}}\left(3.3 .3^{\prime}\right)
$$

where: $\Omega_{k}$ share of trade in commodity $k$ in total trade (exports plus imports)

$\Omega_{k}^{*}$ share of domestic demand for domestic production of $k$ in total demand for domestic production

Choosing the nominal exchange rate as num'raire, the real exchange rate equals the ratio of average world prices and average domestic prices, which is more clearly interpretable than normalisation by eq. (3.3.4).

It has been argued $^{36}$ that the general price level of rule (3.3.4) provides a "no-inflation benchmark", that could be projected exogenously on the basis of observed increases in the domestic price level. However, the inflation rate is the sum of a price movement due to purely monetary inflation and a change in domestic prices vis-a -vis world prices due to a 
shift in real variables (e.g. technical progress, preferences and capital inflow) necessitating a change in the real exchange rate.

From this point of view there is no point in considering $\bar{P}$ in (3.3.4) more easy to project than the domestic price level; normalising by the nominal exchange rate fixes the purely monetary component of the domestic price level, i.e.: $E R=\frac{1}{\mathrm{P}} \bar{D}^{\mathrm{m}}$, where $\overline{\mathrm{P}}^{\mathrm{m}}$ absolute domestic price level after correction for a real exchange rate change (a bar denotes "exogenously fixed"). In a situation that no ex ante overall excess demand through money creation is allowed to arise, the ER would be fixed at unit (base year leve1). Writing PD and $\overline{\mathrm{PW}}$ in eq. (3.3.3') without subscript for the average domestic and world price level, we have:

$$
\text { RER }=\frac{\overline{\mathrm{P}} \overline{\mathrm{W}}}{\overline{\mathrm{P}}}-\overline{\mathrm{P}} \overline{\mathrm{D}}^{-\mathrm{m}}-
$$

and in relative changes $(\cdot)$ :

$$
P \dot{P}=\vec{P} \dot{\bar{D}} \mathrm{~m}+\overline{\mathrm{P}} \dot{\bar{W}}-\mathrm{R} \dot{\mathrm{E}} \mathrm{R}
$$

which decomposes the domestic inflation rate by a purely monetary part,

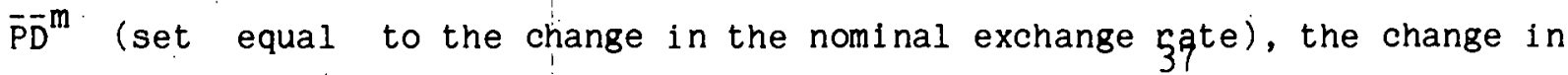
the real exchange rate and the change in world price.

opting for the exchange rate as numeraire, ${ }^{38}$ has the formal advantage that the average level of domestic prices can be interpreted as the inverse of the real exchange rate: it indicates the move of domestic prices vis-ávis world prices (all unit in the base year), necessary to maintain balance of payments equilibrium. The cholce implies that domestic prices are scaled to (exogenous) world prices. Note that the real exchange rate as defined is an ex post equilibrium exchange rate for the model economy, which is subject to given changes in parameters or structural variables. In this sense it could be labelled "forward-looking".

It deviates from a "backward looking" real exchange rate index usually defined as the observed past change in the nominal exchange rate (or some weighted average of exchange rates) corrected for differences in inflation rates or cost indices between the home country and its trading partners (cf. Rhomberg (1976) and Maciejewski (1983) for recent surveys). The precise definition and interpretation of such index depends on the choice of the weights determining the composition of a basket of commodities whose price 
competitiveness should be maintained. Although the actual real exchange rate calculated for a period is clearly not necessarily the equilibrium rate, it may, for example, help to explain a worsening of the trade balance or serve as a proxy of the degree of overvaluation, when real circumstances are relatively constant (e.g. no major shifts in demand or the terms of trade). Conversely, the real exchange rate can be used in a "forward-looking" way for exchange rate policy: the objective may be to keep the real exchange rate constant so as to avoid at least short-term trade balance problems, by timely adjusting the nominal exchange rate to observed or predicted changes in domestic prices relative to world prices. The issue of the choice of the most appropriate real exchange rate definition is not really relevant for our case since in a dynamic general equilibrium framework the changes in the real sphere (technological change, change in demand structure etc.), are endogenous and the equilibrium time path of the real exchange rate automatically follows as the implicit ratio between domestic and world competitors' prices. In other words the question of wage adjustment, shifts in relative domestic prices, supply and demand responses (underlying production, consumption, import and export demand functions), changes in income distribution are all addressed simultaneously. For example, the model may predict the equilibrium real exchange rate over a 5 year period under assumptions about technical progress, capital accumulation and other exogenous variables. Similarly, one may simulate the impact a sustained change in world prices for the country's main export product will exert on domestic relative prices - also relative to world prices - and measure them in deviation from the no-shock equilibrium time path.

An indication of the time path of the real exchange rate may help to formulate a nominal exchange rate policy, when it can be complemented with an independent estimate of the domestic price inflation. For instance, structural changes may - according to the model - require a fall in domestic prices vis-á-vis world prices (a real depreciation), but domestic prices are downwardly sticky; given the domestic inflation rate and the model's predicted real exchange rate, one projects the nominal exchange rate whin would bring about balance of payments equilibrium under the new structural conditions.

In solving the system we asymmetrically adjusted the prices of $\mathrm{K} \mathrm{com-}$ modities according to relative excess demands, leaving the exchange rate 
unchanged. If, however, one is interested in allowing disequilibrium in the foreign exchange market - i.e. changing stock - , the exchange rate will be fixed in addition to another price which then acts as numeraire. For such type of simulations, still of the money-neutral type, we fixed the general price level, changing all prices and exchange rate symmetrically, but scaling them to the fixed general price level. In non-money neutral simulations including money demand and supply (not reported in this book), all prices become endogenous, i.e. the absolute price level is determined and adjusts to the excess supply of money (cf. Adelman and Robinson (1978: 224 a.f.)) ). In such case all prices of commodities are adjusted to excess demand and scaled to an inflation benchmark ( $\bar{P}^{-m}$ above) which moves in response to excess supply of money.

Having chosen the normalisation rule we recall that the equilibrium values for real variables are, in principle, affected by it in case of nonhomogeneity. Since we started from a base year with all, domestic and foreign, prices at unit, the simulation outcome for one rule (say $E R=1$ ) can be compared with that of another rule (say $P_{1}=1$ ). It is possible that all other prices would rise for the ER $=1$ rule, but fall for the $P_{1}=1$ rule, relative prices being, in principle, the same in both cases. But since the change in the general price level will influence some real variables (in non-homogeneous functions), the equilibrium price vector and real outcome will differ between the two rules.

As far non-homogeneous functions were estimated from time series, they reflect the real impact of the changes in the actual price level. As we saw above, the latter can be decomposed into a purely monetary component and a real component. The first is due to excess domestic money creation (assume for simplicity the world price level as constant); the second reflects the change in real conditions, that is the change in the domestic price level necessary to bring about balance of payments equilibrium, in a situation characterised by changing structural parameters and no excess money creation.

The first component is excluded for money-neutral versions of the model; the latter should be allowed in the model to "work" on the real variables determined in non-homogeneous functions, just as it did so in reality. For example, a decrease in the real exchange rate, should be reflected in an 
increase in the domestic price level which is ensured by taking the nominal exchange rate as numeraire.

Relative prices and welfare indices. Since prices play a role in the aggregation of quantities for welfare comparison, we give it some attention here. In order to evaluate the outcomes of policy simulations in terms of aggregate welfare, we have used several (composite) indices, which will be discussed in section 5.4.4. Although we emphasise distributive aspects and focus on the different socio-economic groups and specific welfare indicators, aggregate quantity indices of consumption may still be useful . Such indices are only very rough welfare indicators, since they do not include any distributional dimension.

Index-number tests were proposed by Hicks (1940) as measures of economic welfare; if both the Paasche and Laspeyres quantity indices rise, "real social income" is said to have risen, in the sense that some distribution exists for which every one could be made better off, in other

$$
Q^{L}=\frac{\sum P_{k}^{o} Q_{k}^{t}}{\sum P_{k}^{0} Q_{k}^{0}}>1 \text { and } Q^{P}=\frac{\sum P_{k}^{t} Q_{k}^{t}}{\sum P_{k}^{t} Q_{k}^{o}}>1
$$

where: $Q^{L}, Q^{P}$ Laspeyres and Paasche quantity indices

The outcome is undetermined when the Paasche index falls, but Laspeyres increases. To be on the safe side we used the "double test" for comparison of real incomes between policy simulations, still recognising their restrictiveness in terms of income distribution. It is clear that the choice of numeraire does not affect welfare comparisons of this type.

Stability and uniqueness. For our purposes, a detailed study of the stability and uniqueness properties of the model was considered to be out of scope, and, secondly, practically impossible given the size of the model and computer time constraints. We have chosen for a practical orientation and solved the model by trial and error in a computer-time-efficient way, based on "tâtonnement". In this, we followed the approach and experience of other model builders, that successfully applied "tatonnement", in particular to commodity markets with relatively few interdependencies ${ }^{39}$. Factor markets with considerable substitution across factors (e.g. labour types) tend to be 
Figure 3.3.1: A sketch of the solution algorithm

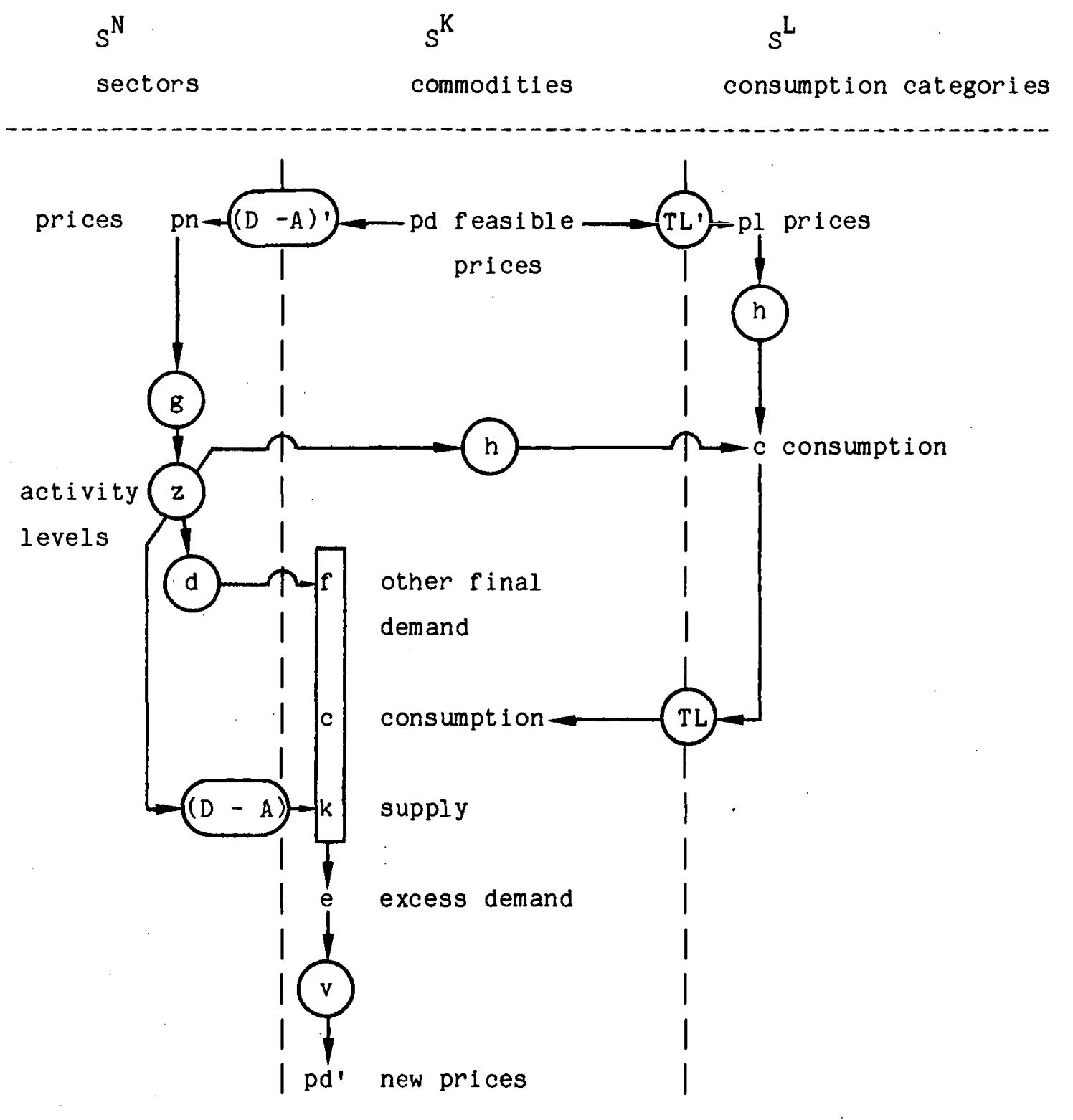

\section{Notes:}

8 production and factor demand functions

$\mathrm{h}$ income distribution and consumption functions

d income distribution and other demand functions

$\mathrm{v}$ new prices as a function of excess demand

D-A net production matrix (sectors-commodities)

TL consumption 'make' matrix (commodities-consumption categories) 
more interdependent and less suited for "tatonnement" procedures; this was not relevant in our case, however, since wage rates were exogenous to the main, current year part and allowed to adjust only gradually in the updating part, thereby allowing unemployment.

In practice, we proceeded in three steps. First, we assumed for each selected simulation an equilibrium to exist and tried to find it by "tâtonnement". Second, convergence of the adjustment rule towards the equilibrium was searched by varying the dampening factors. It is known that premultiplying the matrix of a system of differential equations, may make an unstable system stable (see section 2.3 above). Third, local uniqueness was roughly investigated by varying the initial price vector to see whether the same equilibrium was reached.

Figure 3.3.1 illustrates how the price adjustment procedure globally works for the model. An initial price vector for commodities in the $s^{K}$ space defines a sectoral net price which enters production functions (function $g$ ) in the $S^{N}$ space. Activity levels determine the supply of commodities in the $\mathrm{s}^{\mathrm{K}}$ space as well as the incomes that enter demand functions: prices of consumption categories in the $s^{L}$ space, together with incomes, determine consumption (function $h$ ), while incomes and commodity prices determine other final demand (function d). The excess of demand over supply determines a new price vector according to a price change function (function $v$ ), defined by an appropriate "tâtonnement" rule. If all functions are continuous, and under certain properties of the set of feasible prices, the mapping of (pd $e \mathrm{~s}^{\mathrm{K}}$ ) into itself has a fixed point $\mathrm{f}(\mathrm{pd})=\mathrm{pd}$, 1.e. an equilibrium price vector exists.

The price adjustment function $v$ has been defined as follows. First, a distinction was made between commodities whose price is determined on the domestic market and those for which the world price is determinant. The world price is determinant for those exportable commodities facing a perfectly elastic ${ }^{40}$ foreign demand and for which the domestic equilibrium price would lie below the world price (times effective exchange rate). Similarly, the world price (times effective exchange rate) determines the domestic price for those importable commodities for which the import substitution elasticity is infinite and for which the domestic equilibrium price would lie above the world price. The former is quite plausible for a small country, although producers may still face differences between domestic and 
foreign prices; the latter is not even for a small country and some substitutability can be observed at feasible levels of aggregation. Two adjustment rules were applied.

a) World price determines domestic price, perfectly elastic export demand If $\mathrm{PD}_{\mathrm{k}} \leqq \overline{\mathrm{PW}}_{\mathrm{k}} \overline{E E R}_{\mathrm{k}}$, then move the domestic price gradually to the given world price:

$$
P D_{k}^{\prime}=\lambda P D_{k}+\left(1-\lambda_{k}\right) \overrightarrow{P W}_{k} E E R_{k}
$$

where: $E E R_{k}$ effective exchange rate which implies the domestic price moves towards the world price. 41 If $P D>\bar{P}_{k} E E R_{k}:$ (see case $b$ ).

b) Price determined on domestic market

This case holds for: non-tradables (i), for exportables with less than infinite price elasticity (ii), for exportables with infinite demand elasticity that are not (yet) competitively priced (iii), and for importables (iv). The adjustment rule is:

$$
P D_{k}^{\prime}=P D_{k}\left(1+\lambda_{k}\left(\operatorname{EXC}_{k}^{\prime} x_{k}\right)\right)
$$

where: $\operatorname{EXC}_{k} / X_{k}$ excess demand relative to domestic supply

The dampening factor $\lambda_{k}$ is specific for each commodity and is reduced in order to limit price changes to a maximum and to prevent alternating:

$$
\lambda_{k}=\min \left(\Lambda \lambda_{k}^{*} \operatorname{RED}_{k} ; \mathrm{PD}_{k}^{\max } /\left(\operatorname{EXC}_{k} / \mathrm{X}_{k}\right)\right)
$$

where: $\Lambda$ general dampening factor

$$
\begin{aligned}
& \lambda_{k}^{*} \text { fixed commodity-specific dampening factor } \\
& R_{k} \text { dampening reduction factor which is less than one (varying } \\
& \text { from } 0.2 \text { to } 0.8 \text { ) if excess demand switches sign between } \\
& \text { previous and current iteration and } 1 \text { otherwise } \\
& \mathrm{PD}_{\mathrm{K}}^{\mathrm{max}} \text { maximum relative price change (set between } 1 \text { and } 4 \% \text { ) }
\end{aligned}
$$


The $\lambda_{k}^{*}$ were sometimes made inversely proportional to the magnitude of the supply response for the commodity. 42

As observed above the complete dynamic version of the model is timerecursive: at the end of each year, the equilibrium solution of the main part having been found, the structural variables are endogenously (some exogenously) altered in the udating part before a new sequence of "main" iterations starts.

One main iteration consitutes a mapping of a price vector to a new one. The model is formulated in a way that this mapping process is literally "straightforward" as one might gather from the sequence of blocks as described above: with the exception of few Instances each endogenous variable is calculated from variabies that were already calculated. The exceptions are:

1) the production block where one has to 1terate over production and employment in order to solve CES-production functions and marginal conditions;

ii) the sectoral allocation of scarce wage labour skills, where one has to iterate over: a) production $\rightarrow$ b) desired wage labour demand and wage labour supply $\rightarrow$ c) allocation of labour $\rightarrow$ a) return to (new) production;

iii) the allocation of employment to household groups, where one has to iterate over: a) distribution of employment on the basis of accessto-jobs-parameters and supply $\rightarrow$ b) comparison with actual supply; if "job-quotum" exceeds supply for one group, set its employment equal to its supply and distribute remalning jobs to remaining households, so back to $\rightarrow$ to a).

\subsubsection{Use of the Model}

To close this general outline of the model, some remarks on its possible use as well as its limitations seem in order.

The model is a tool for policy making, but not as a forecasting model. Rather, its interest iles in its ability to describe the effects (as well as the mechanisms that lead theretol of exogenously introduced policies. Possible simulations are given below, by way. of example; a selection from them will be explored in chapters 7 and 8 . 
a) Changes in the parameters that describe the structural impact of basic needs satisfaction: which medium-run effects can be expected when basic needs satisfaction has a larger (smaller) impact on certain structural vari ables?

b) Changes in government policy instruments (tax rates, government current and capital expenditure, changes in access of various socio-economic groups to government services): what will be the changes in basic needs satisfaction, in income distribution, in employment, in the production structure etc., if certain policy packages are introduced?

c) Changes in medium-run structural characteristics of the country: population growth, foreign savings and transfers, urban-rural composition of the population, world market prices, production function parameters, import function parameters etc.

d) Changes in "closure rules": the expenditures of a varlety of institutions or households can be specified as the residual item which brings about income-expenditure equilibrium. For example, government investment may be residual, household consumption, enterprise investment, or foreign savings, etc.

e) Various exogenous prices can be modified in order to analyse the effects of direct income policies: changes in wage rates, in interest rates, in the exchange rate, etc.

The reader interested in the precise specification and estimation of the model should now continue with the second part (chapters 4-6), whereas the less technically oriented reader may pass on to chapter 7 on policy simulations. 
Notes

1. See Dervis et al. (1982) for a recent survey and empirical examples. In most of the applications so far relatively little attention is paid to basic needs issues, with the notable exception of Adelman and Robinson (1978). Such attention is given by many multi-sectoral models which are not of the general equilibrium type and assume prices to be exogenous. Examples of such models are found in the World Employment Programme of the ILO (Hopkins and Van Der Hoeven 1981; Rodgers, Hopkins and wery (1978) ). See also the more extensive discussion in section 2.2.

2. Cf. the discussion in section 2.2.

3. See Pyatt and Round (1979) and Defourny and Pyatt (1984).

4. Note that the composite price is the average price for imported and domestic goods, such that $\vec{P} O=D P D+M \overrightarrow{P W} E R$, where $D$ and $M$ are the domestic and foreign components of demand and $O$ the volume of the composite good.

5. The detailed discussion of each of the composing blocks of the main part is found in chapter 4.

6. The detailed discussion of each of the block of the updating part is found in chapter 5 .

7. See, for example, Christensen, Jorgensen \& Lau (1973).

8. See, for example, Lysy and Taylor (1980), Adelman \& Robinson (1978).

9. Intermediate inputs are of both domestic and foreign origin. This is reflected by a composite good, the composition of which depends on relative prices. See section 3.2 .4 below.

10. For simplicity's sake indirect tax rates have been omitted in this exposition.

11. More precisely, $d \mathrm{dN}_{n} / d z_{n}$ is the change in the net price of the sector which the market will bear when the sector changes its activity level.

12. Institutional forces largely determine the wage rate, which is $f$ ar from market clearing. A more careful study of the relationship between employment and wage rates has shown that wages hardly respond to (changes in) unemployment rates. See also section 4.1 and appendices.

13. Difference in wages paid, in control of information, in influence on government policies, etc.

14. Note that the coefficient of correlation is invariant to a uniform percentage increase of one of the income sources; for example, an increase in all interest rates or wage rates. 
15. The average and variance of the number of income earners in a household group depend on the (distribution function of the) household size. See the updating Part II.

16. Theoretically, it would have been more satisfying to apply tax functions at the level of income earners. The household level has been taken due to data constraints. Moreover, tax paid by an income earner is to some extent related to the income position of the household she belongs to.

17. The risk of unemployment does seem to be related to the income of the household or income earner. Since, in the case under study, unemployment allowances are rather small, we feel justified to neglect this element.

18. Total wealth, interest rates and the absolute price level (affecting demand for cash balances) are among those excluded variables.

19. This element may or may not depend on relative prices $P_{K}$. Fixed coefficients is the most simple case. Note that

$\mathrm{PL}_{1}=\sum_{K_{1}} \mathrm{TL}_{\mathrm{kl}} \mathrm{P}_{\mathrm{K}_{\mathrm{N}}}\left(3.2 .24^{\prime}\right)$, where: $\mathrm{PL}_{1}$ market prices, $\mathrm{P}_{\mathrm{K}}$ producer prices, implying thât the mapping from market prices to producêr prices, is implicit in [TL $\left.\mathrm{Tl}_{\mathrm{k}}\right]$. The next most simple form with which we have experimented is a CES-Form, such that: $T L_{k l}=C a_{k l}\left(P L_{l}^{\prime} P_{k}\right) \sigma_{1}$

where: $\mathrm{PL}_{1}$ CES-aggregation of pricés of composing commodities

20. For a discussion of the flow of funds in the framework of a social accounting matrix, see section 6.3 .

21. Desired investment was either exogenous or determined as a function of growth in output and cost of capital.

22. Since public services are not sold, an imputed price of the capital services embodied in the government capital stock needs to be calculated. The value of services thus imputed is allocated to households, both as imputed income and consumption, and to the government both as imputed transfers to households and as imputed receipts from sales of its services. Note that GDP rises by the same amount. One way by which to value capital services is to apply the average interest rate on government debt plus a depreciation rate to the current value of accumulated investment.

23. Note that so far we have only dealt with one specific way of closing the model, namely, by assuming that aggregate savings determine aggregate investment. Other closure rules are introduced later.

24. To the export supply corresponds a domestic supply which has the same form as $(3.2 .41)$.

25. As we have seen above, in the case of price discrimination export markets are cleared separately and only the domestic components of demand and supply are taken for the derivation of domestic market equilibrium. 
26. We neglect here the problem related to the commodity 'commerce', which is a component of commodities in producer prices.

27. This depends largely on the availability of land and on government policies relating to the exploration of new land.

28. Economically active persons are those who work or want to work (i.e. the (un)employed); income earners are the economically active plus recelvers of transfer income, i.e. rentiers, pensioners, handicapped etc.

29. Note that the per capita consumption functions should indeed have a neat form. As we have seen above, the additivity constraint introduces deviations from lognormality such that the proposed fraction can only be approximated.

30. Careful calibration and specification ensured that Walras' Law holds: every sucre or dollar earned is also spent; in practice the sum of excess demands was al ways near to zero.

31. Many theoretical and empirical general equilibrium models satisfy the homogeneity condition; it is sometimes postulated as a property of the model but not verified throughout the model. Nor is the condition of homogeneity very obvious or plausible on logical grounds; moreover, empirical studies on consumer demand could not confirm it (see Deaton and Muellbauer (1980: 69-80).

32. Such was the case in the simulations repoted in this book.

33. Cf. Keller (1980: 151-154).

34. Labelled "strong local uniqueness" by Adelman and Robinson (1978: 225).

35. See Dornbusch (1980: 36-116) for a discussion of tradable and nontradable goods, as well extensive references.

36. Dervis, de Melo and Robinson (1982: 192 a.f.)

37. For simplicity, we assume world prices to be constant from here on. Note that the exchange rate change, $E \dot{R}$, can be replaced by a trade-weighted average of exchange rate changes in trading partner or competitors' countries in the çase of generalised floating; in the same way, world price changes, $\overline{\mathrm{P}}_{\mathrm{K}}$, would be written as a trade-weighted average of price changes of trading partners (weights equalling the share in the home country's trade). In view of the scope of our study, we leave these questions - in particular the choice of appropriate weights - aside and assume uniform world prices, given to the country under study, and abstract from differential movements in prices and exchange rates of competing countries (see e.g. Bautista and Riedel (1982) and Maciejewski (1983) for a recent study resp. review).

38. Cf. Dixon et al. (1982: 146-8). Note that the choice is a matter of format, not substance. 
39. See Adelman and Robinson (1978), Dungan (1980) and Lysy and Taylor (1980: 166 a.f.) for such experiences.

40. In practice "infinite" meant a price elasticity of demand of 30 .

41. We abstracted in this presentation from the problem related to the domestic trade mark-up. The export supply price, which will be equalised to the world price in domestic currency, is a market price, i.e. when $\mathrm{m}_{\mathrm{k}} \mathrm{PD}_{\mathrm{k}}$ denotes market price:

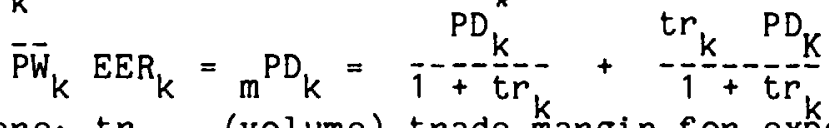

where: $\operatorname{tr}_{k}$ (volume) trade margin for export of $k$

$\mathrm{PD}_{\mathrm{K}}$ price of "domestic trade"

Since the equilibrium price of "domestic trade", $P D_{K}$, is to be found and depends a.o. on the demand for "domestic trade" for exports of commodity $k$ - it is unwise to set directly the domestic price $\mathrm{PD}_{k}$ at the level following from eq. (3.3.7') (1.e. $\mathrm{PD}_{k}^{*}$ ). Instead we calculated $\mathrm{PD}_{\mathrm{K}}^{*}$ at the new "trade" price, PD', that is after adjustment for excess demand and had $P D_{k}$ moving slowly towards this price, $P D_{k}^{*}$, to prevent alternating: $P D_{k}^{\prime}=\alpha{ }^{k} D_{k}+(1-\alpha) P D_{k}$. The problem originates in the fact that trade margins for exports are different from trade margins for domestic sales. See section 4.6 for more detail.

42. The procedure deviates from Adelman and Robinson (1978) who first adjust per unit value added to excess demand and then calculate the commodity price vactor with the dual of the Leontief inverse. Since our model distinguishes sectors (for which per unit value added matters) from commodities this was not possible. 
ISS-PREALC "Planning for Basic Needs in Latin America" WORKING PAPER SERIES ${ }^{1 ;}$

No. for Author

Series

1

Rob Vos

Rob Vos

2

(1)

3

R. Vos;

A. Vos and

S. van der Werff

4

Rob Vos

L. Barreiros

6
patterns in Ecuador, The Hague,
october 1982 (revised version
april 1985).

Title

Ecuador: External dependence and capital accumulation, Quito December 1981

Ecuador: Rural household savings capacity and investments, 1974-75, Quito December 1981 .

Rural development, supply and access to basic (public) services. A case study of the province of Bolivar, Ecuador, May 1. 982 .

Access to basic services and the public expenditure incidence, Ecuador, 1970-80, Quito November 1982 .

Poverty and household consumption

Apiti 1985)

Capital accumulation and basic needs, Quito October 1982.

1) The working papers numbered below are obtainable on request from the fublications Office, Institute of Social Studies, P.O. Box 90733, 2509 LS, The Hague, The Netherlands. 


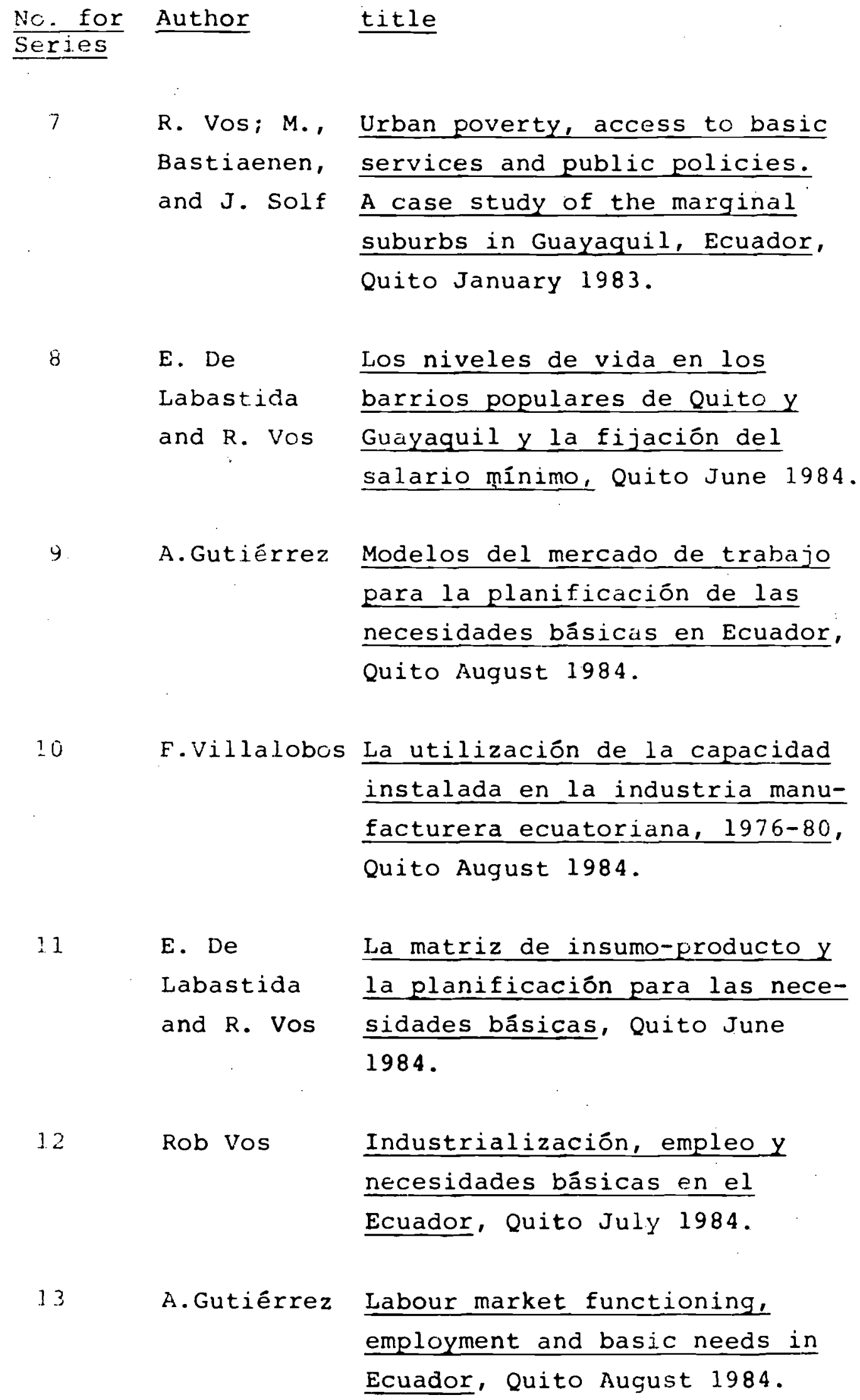




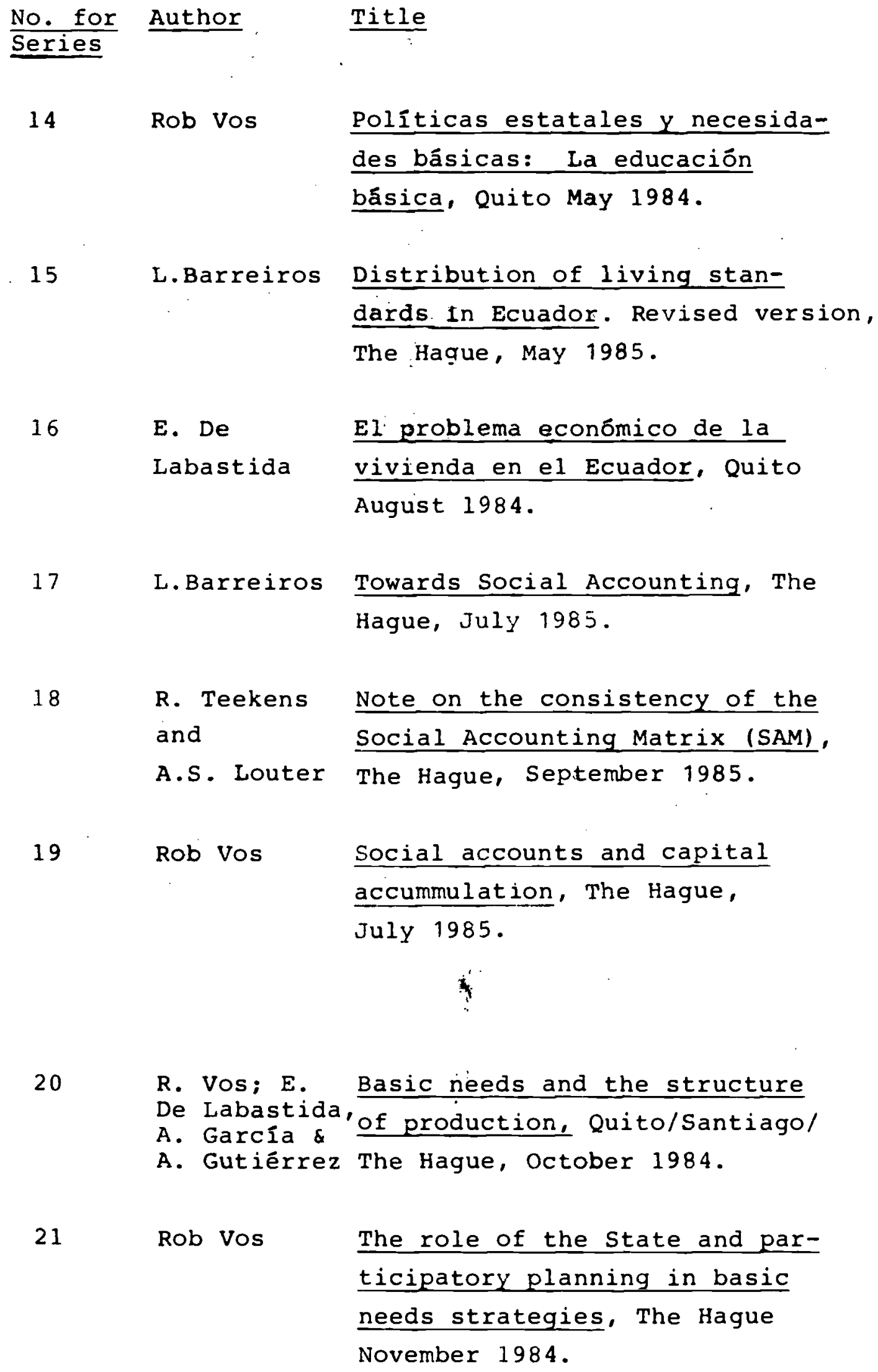

16 E. De

Labastida

El problema económico de la vivienda en el Ecuador, Quito August 1984 .

17 L.Barreiros Towards Social Accounting, The Hague, July 1985.

18 R. Teekens Note on the consistency of the and Social Accounting Matrix (SAM), A.S. Louter The Hague, September 1985.

Social accounts and capital accummulation, The Hague, July 1985.

R. Vos; E. Basic needs and the structure

De Labastida, of production, Quito/Santiago/

A. Gutiérrez The Hague, October 1984 .

The role of the state and participatory planning in basic needs strategies, The Hague November 1984 . 


\begin{tabular}{|c|c|c|}
\hline$\frac{\text { No. for }}{\text { Series }}$ & Author & Title \\
\hline \multirow[t]{3}{*}{22} & Rob Vos & Government policies, inequality \\
\hline & & and basic needs in Ecuador, \\
\hline & & Quito, July 1985. \\
\hline \multirow[t]{3}{*}{23} & L.Barreiros & Operationalizing concepts and \\
\hline & & measurement of poverty and basic \\
\hline & L. Barreiros & $\begin{array}{l}\text { needs, The Hague, July } 1985 . \\
\text { Ecuador's development profile }\end{array}$ \\
\hline \multirow{2}{*}{24} & & and basic needs performance, \\
\hline & & The Hague, July 1985. \\
\hline \multirow[t]{2}{*}{25} & L. Barreiros & A Social Accounting Matrix for \\
\hline & & Ecuador, The Hague, July 1985. \\
\hline \multirow[t]{4}{*}{26} & A. Kouwenaar & Methodological notes on the \\
\hline & & sample design of household \\
\hline & & budget surveys, Ecuador 1975 \\
\hline & & and $1978-79$, The Hague. \\
\hline
\end{tabular}

A. Kouwenaar A General Equilibrium Basic Needs

R. Teekens Policy Model, The Hague, November 1985. The Hague, November 1986

Income distribution and consumtion patters among households, The Hague, June 1985.

A Data Base for the General Equilibrium Basic Needs Policy Model, The Hague. December 1985.

A. Kouwenaar Dynamic simulations with a General Equilibrium Basic Needs Model, The Hague.

31 J.V. Alarcon Transition Growth and Basic Needs in Ecuador. A historical analysis, The Hague, October 1985. 
Working Papers to be Obtained through PREALC

(PREALC, casilla 618, Santiago de Chile)

B. Tomic \& R. Gonzalez

A. Garcia

PREALC/ISS

B. Tomic

A. Garcia

B. Tomic

A. Garcia (editor)
Municipio y estado. Dimensiones de una relacion clave, PREALC/ISS, Monograflas sobre empleo No.27, Santiago de Chile, July 1983 .

Planificación alimentaria. Esquema metodologico para el análisis de experiencias en en América Latina, PREALC/ISS, Monografías sobre empleo No.28, Santiago de Chile, August 1983.

Planificación para las necesidades básicas en America Latina, PREALC/ISS, Monografias sobre empleo No.29, Santiago de Chile, August 1983.

Necesidades básicas y participación popular. Opciones eticas y metodologlcas, PREALC/ISS Monograflas sobre empleo No.30, Santiago de Chile, September 1983.

La situación alimentaria en Costa Rica, PREALC/ISS, Monograflas sobre empleo No.31, Santiago de Chile, September 1983.

Planificacion participativa $y$ descentralizada para las necesidades basicas, PREALC/ISS, Monograflas sobre empleo No.32, Santlago de Chile, september 1983.

Ei. problema alimentario y nutricional en Chile: Diagnostico y evaluación de polfticas PREALC/ISS, Monograflas sobre empleo No.33, Santiago de Chile, September 1983. 
B. Tomic

A. Garcia

H. Duran \& S. Soza

B. Tomic

A. Garcia

A. Garcia

B. Tomic

M. Castillo \&

A. Garcia
Descentralización y participación popular:

La salud rural en Costa Rica, PREALC/ISS, Monograflas sobre empleo No.34, Santiago de Chile, September 1983.

Un intento de planificacion alimentaria integral: El programma PAN-DRI de Colombia, PREALC/ISS, Monograflas sobre empleo No.35, Santiago de Chile, September 1983.

Consideraciones acerca del problema de la vivienda en America Latina, PREALC/ISS, Monograflas sobre empleo No.36, Santiago de Chile, March 1984.

Examen critico de tres intentos oficiales de planificación descentralizada y participativa, PREALC/ISS (S 842), Monografía sobre Empleo No. 37, Santiago de Chile, April 1984 .

Basic Needs and the structure of production, PREALC/ISS (S 843), Monografía sobre Empleo No. 38, Santiago de Chile, May 1984.

Industrialización para el desarollo equitativo, PREALC/ISS (S 844) Monografía sobre Empleo No. 39, Santiago de Chile, October 1984 .

Participación popular y desarrollo en la base, PREALC/ISS (S 845), Monografía sobre Empleo No. 40, Santiago de Chile, October 1984 .

Una matriz de contabilidad social para Chile 1977. Aspectos metodologicos y resultados, PREALC/ISS (S 846), Monografia sobre Empleo No. 41, Santiago de Chile, December 1984. 
M. Castillo \&

A. Garcia

H. Szretter

A. Gutiêrrez

A. Gutiérrez

A. Gutierrez

H. Szretter

A. Gutiérrez
Cambio estructural e industrializacion: Análisis de escenarios, PREALC/ISS (S 847) Monografía sobre Empleo No. 42, Santiago de Chile, December 1984.

Ecuador: Nutricion y oferta de alimentos básicos, PREALC/ISS (s 848) Monografía sobre Empleo No. 43, Santiago de Chile, December 1984 .

Empleo y crecimiento en Ecuador 1970-1982: Tendencias recientes $y$ lineamientos de polftica, PREALC/ISS (S 849 ) Monografia sobre Empleo No. 44, Santiago de Chile, December 1984 .

Ecuador: Salarios, empleo e ingresos 1970-1982, PREALC'ISS (S 8410), Monografía sobre Empleo No. 45, Santiago de Chile, December 1984 .

Modeios dei mercado de trabajo para la planificacion de las necesidades basicas en Ecuador, PREALC/ISS (S 8411), Monografia sobre Empleo No. 46, Santiago de Chile, December 1984.

México: Las necesidades básicas de alimentacion, PREALC/ISS (S 851), Monografía sobre Empleo No. 47, Santiago de Chile, May 1985.

Mercado de trabajo y necesidades básicas en Ecuador, PREALC/ISS (S 852), Monograf sobre Empleo No. 48, Santiago de Chile, May 1985 . 
